\title{
Cytotoxicity and antibacterial activity of gold-supported cerium oxide nanoparticles
}

\author{
This article was published in the following Dove Press journal: \\ International Journal of Nanomedicine \\ 27 November 2014 \\ Number of times this article has been viewed
}

\author{
K Suresh Babu ${ }^{1, \dagger}$ \\ M Anandkumar ${ }^{1, \dagger}$ \\ TY Tsai ${ }^{2}$ \\ $\mathrm{TH} \mathrm{Kao}{ }^{2}$ \\ B Stephen Inbaraj ${ }^{2}$ \\ $\mathrm{BH} \mathrm{Chen}^{2,3}$ \\ 'Centre for Nano Sciences and \\ Technology, Madanjeet School \\ of Green Energy Technologies, \\ Pondicherry University, Kalapet, \\ India; ${ }^{2}$ Department of Food Science, \\ ${ }^{3} \mathrm{Graduate}$ Institute of Medicine, \\ Fu Jen University, Taipei, Taiwan \\ †These authors contributed equally \\ to this work
}

Background: Cerium oxide nanoparticles $\left(\mathrm{CeO}_{2}\right)$ have been shown to be a novel therapeutic in many biomedical applications. Gold $(\mathrm{Au})$ nanoparticles have also attracted widespread interest due to their chemical stability and unique optical properties. Thus, decorating $\mathrm{Au}$ on $\mathrm{CeO}_{2}$ nanoparticles would have potential for exploitation in the biomedical field.

Methods: In the present work, $\mathrm{CeO}_{2}$ nanoparticles synthesized by a chemical combustion method were supported with $3.5 \% \mathrm{Au}\left(\mathrm{Au} / \mathrm{CeO}_{2}\right)$ by a deposition-precipitation method. The as-synthesized $\mathrm{Au}, \mathrm{CeO}_{2}$, and $\mathrm{Au} / \mathrm{CeO}_{2}$ nanoparticles were evaluated for antibacterial activity and cytotoxicity in RAW 264.7 normal cells and A549 lung cancer cells.

Results: The as-synthesized nanoparticles were characterized by X-ray diffraction, scanning and transmission electron microscopy, and ultraviolet-visible measurements. The X-ray diffraction study confirmed the formation of cubic fluorite-structured $\mathrm{CeO}_{2}$ nanoparticles with a size of $10 \mathrm{~nm}$. All synthesized nanoparticles were nontoxic towards RAW 264.7 cells at doses of $0-1,000 \mu \mathrm{M}$ except for $\mathrm{Au}$ at $>100 \mu \mathrm{M}$. For A549 cancer cells, $\mathrm{Au} / \mathrm{CeO}_{2}$ had the highest inhibitory effect, followed by both $\mathrm{Au}$ and $\mathrm{CeO}_{2}$ which showed a similar effect at 500 and $1,000 \mu \mathrm{M}$. Initial binding of nanoparticles occurred through localized positively charged sites in A549 cells as shown by a shift in zeta potential from positive to negative after 24 hours of incubation. A dose-dependent elevation in reactive oxygen species indicated that the pro-oxidant activity of the nanoparticles was responsible for their cytotoxicity towards A549 cells. In addition, cellular uptake seen on transmission electron microscopic images indicated predominant localization of nanoparticles in the cytoplasmic matrix and mitochondrial damage due to oxidative stress. With regard to antibacterial activity, both types of nanoparticles had the strongest inhibitory effect on Bacillus subtilis in monoculture systems, followed by Salmonella enteritidis, Escherichia coli, and Staphylococcus aureus, while, in coculture tests with Lactobacillus plantarum, S. aureus was inhibited to a greater extent than the other bacteria.

Conclusion: Gold-supported $\mathrm{CeO}_{2}$ nanoparticles may be a potential nanomaterial for in vivo application owing to their biocompatible and antibacterial properties.

Keywords: cerium oxide nanoparticles, gold supported cerium oxide, cytotoxicity, antibacterial activity, cellular uptake, reactive oxygen species

\section{Introduction}

Cerium oxide $\left(\mathrm{CeO}_{2}\right)$ nanoparticles (NPs) have been studied recently for their antimicrobial activity, ${ }^{1,2}$ due to the redox nature of $\mathrm{CeO}_{2}$ whereby the oxidation state switches between $\mathrm{Ce}^{3+}$ and $\mathrm{Ce}^{4+}$ depending on the external environment. This redox nature of $\mathrm{CeO}_{2} \mathrm{NPs}$ aids in inhibiting bacterial growth and scavenging free radicals. ${ }^{3}$ The antibacterial activity of $\mathrm{CeO}_{2}$ NPs not only depends on nanoparticle size but also on the medium in which they are dispersed, as well as other factors such as $\mathrm{pH}$ and salt concentration. ${ }^{1}$ When NPs are tested in vivo, it is necessary to evaluate their cytotoxicity effect because free radicals can affect both normal and abnormal cells. ${ }^{4}$
Correspondence: $\mathrm{BH}$ Chen Department of Food Science, Fu Jen University, Taipei 242, Taiwan

Tel +88 6229053626

Fax +88622905 I2I5

Email 002622@mail.fju.edu.tw submit your manuscript | www.dovepress.com

Dovepress

http://dx.doi.org//0.2147/IJN.S70087
International Journal of Nanomedicine 2014:9 55I5-553।

(c) (i) (5) 2014 Babu et al. This work is published by Dove Medical Press Limited, and licensed under Creative Commons Attribution - Non Commercial (unported, v3.0) License. The full terms of the License are available at http://creativecommons.org/licenses/by-nc/3.0/. Non-commercial uses of the work are permitted without any further permission for Deve Medical Press Limited, provided the work is properly attributed. Permissions beyond the scope of the License are administered by Dove Medical Press Limited. Information on how to request permission may be found at: http://www.dovepress.com/permissions.php 
Accordingly, the cytotoxicity also refers to death of healthy cells, mainly caused by production of reactive oxygen species (ROS). ${ }^{4}$ However, $\mathrm{CeO}_{2} \mathrm{NPs}$, being natural ROS scavengers, can generate ROS in certain specific environments and damage cancer cells. Auffan et $\mathrm{al}^{5}$ reported a toxicity of $7 \mathrm{~nm} \mathrm{CeO}{ }_{2} \mathrm{NPs}$ that involved damage to DNA in human fibroblasts, mainly due to oxidative stress caused by the interaction between redox $\mathrm{CeO}_{2}$ NPs and other organic molecules. The cytotoxicity of $\mathrm{CeO}_{2} \mathrm{NPs}$ was also reported by Li et $\mathrm{al}^{6}$ who demonstrated a protective effect on bacteria during initial exposure to $\mathrm{CeO}_{2} \mathrm{NPs}$ because of the scavenging effect of free radicals, yet prolonged exposure could result in generation of ROS leading to toxicity. This phenomenon can eventually extend to growth of normal cells or inhibition of cancer cells.

Metal NPs, like gold ( $\mathrm{Au}) \mathrm{NPs}$, have several potential applications in the biomedical field, including antibacterial activity. ${ }^{7-9}$ Au NPs combined with antibiotics have been reported to show improved antibacterial activity compared with antibiotics alone. ${ }^{7}$ Use of Au NPs as an antibacterial agent is mainly due to their unique biocompatibility, which depends on their size, shape, and concentration, as well as the nature of their surface functionalization. ${ }^{5,10-12}$ Chen et al ${ }^{10}$ illustrated the size-dependent toxic effect of Au NPs in mice, with a size of 8-37 $\mathrm{nm}$ being more toxic and a size in the range of 3-100 $\mathrm{nm}$ being less toxic. Thus, combining the antibacterial activities of Au NPs and $\mathrm{CeO}_{2} \mathrm{NPs}$ would be a novel approach for developing a nanomaterial with strong antibacterial activity. Although many researchers have employed a combination of $\mathrm{Au}$ and $\mathrm{CeO}_{2}$ in catalytic applications, few reports are available concerning the biomedical applications of such a combination. A previous study by Menchón et al ${ }^{13}$ demonstrated that $\mathrm{Au}$-coated $\mathrm{CeO}_{2} \mathrm{NPs}\left(\mathrm{Au} / \mathrm{CeO}_{2} \mathrm{NPs}\right)$ had better ROS scavenging activity, biocompatibility, and peroxidase activity than $\mathrm{CeO}_{2} \mathrm{NPs}$. However, the antibacterial activity of $\mathrm{Au} / \mathrm{CeO}_{2}$ NPs remains unexplored.

Several authors have demonstrated Lactobacillus plantarum to have good antibacterial activity owing to its intrinsic ability to produce several antimicrobial substances, such as organic acids, hydrogen peroxide, bacteriocins, or related compounds. ${ }^{14-16}$ Of these metabolites, bacteriocins are of particular interest because there have been several reports demonstrating their antimicrobial efficiency across a broad spectrum of microbes. ${ }^{17-19}$ Although many bacteria can produce bacteriocins, L. plantarum is chosen in this study due to its Generally Regarded As Safe status. Bacteriocins are proteinaceous antimicrobial compounds produced extracellularly during the stationary phase of bacterial culture..$^{15,17}$
Bacteriocins produced by Lactobacillus species are known as "plantaricins", and their stability varies depending on the specific physicochemical environment and Lactobacillus species used..$^{14,19-21}$ In view of this, we intended to coculture each test bacteria with $L$. plantarum to evaluate the possible synergistic antibacterial effect by $L$. plantarum and as-synthesized $\mathrm{CeO}_{2} \mathrm{NPs}$ or $\mathrm{Au} / \mathrm{CeO}_{2} \mathrm{NPs}$. Presently, there are no reports available on determining the antibacterial efficacy of $\mathrm{Au} /$ $\mathrm{CeO}_{2}$ NPs in a coculture where the culture has more than one bacterial species. The present work focuses on the cytotoxic effects of $\mathrm{Au} \mathrm{NPs}, \mathrm{CeO}_{2} \mathrm{NPs}$, and $\mathrm{Au} / \mathrm{CeO}_{2} \mathrm{NPs}$ in normal cells and in lung cancer cells, as well as their antibacterial activity against Gram-positive and Gram-negative bacteria in both monoculture and coculture systems. In addition, the underlying mechanism of cytotoxicity and antibacterial activity is elucidated.

\section{Materials and methods Materials}

Cerium nitrate hexahydrate $\left(\mathrm{Ce}\left(\mathrm{NO}_{3}\right)_{3} \cdot 6 \mathrm{H}_{2} \mathrm{O}, 99.9 \%\right.$, SigmaAldrich, St Louis, MO, USA), glycine $\left(\mathrm{NH}_{2} \cdot \mathrm{CH}_{2} \mathrm{COOH}\right.$, Fisher Scientific, Mumbai, India), chloroauric acid $\left(\mathrm{HAuCl}_{4}\right.$, Loba Chemie, Mumbai, India), and sodium borohydride $\left(\mathrm{NaBH}_{4}\right.$, Sigma-Aldrich) were used for synthesis of both $\mathrm{CeO}_{2}$ and $\mathrm{Au}$-impregnated $\mathrm{CeO}_{2}$ nanoparticles.

RAW 264.7 macrophage cells and A549 human lung adenocarcinoma epithelial cells were obtained from the Taiwan Food Industry Development Research Institute (Hsinchu, Taiwan) and their corresponding cell culture media, Dulbecco's Modified Eagle Medium (DMEM) and Roswell Park Memorial Institute (RPMI)-1640 medium, respectively, were supplied by HyClone (Logan, UT, USA). Hank's Balanced Salt Solution and fetal bovine serum were also sourced from HyClone, while $2.5 \%$ trypsin-ethylenediamine tetraacetic acid and penicillin-streptomycin were from Invitrogen (Carlsbad, CA, USA). Dimethyl sulfoxide and chemical reagents such as sodium bicarbonate and 3-(4,5dimethylthiazol-2-yl)-2,5-diphenyltetrazolium bromide (MTT) were supplied by Sigma-Aldrich. Ethanol (95\%) was obtained from the Taiwan Tobacco and Wine Bureau (Tainan, Taiwan). A fluorescence dye, ie, 5-(and 6-)-chloromethyl-2,7-dichlorodihydro fluorescein diacetate, from Molecular Probes (Eugene, OR, USA) was used for measuring intracellular ROS formation by a microplate spectrofluorometer (SpectraMax ${ }^{\circledR}$, Molecular Devices, CA, USA). The Versa Max enzyme-linked immunosorbent assay (ELISA) reader was from Molecular Devices, the carbon dioxide incubator (SCA-165DS) was from Astec (Fukuoka, Japan), 
the inverted microscope (TS100) was from Nikon (Tokyo, Japan), and the 4BC-24 model laminar flow hood was from Jau-Hsin Co (Taipei, Taiwan).

Of the four pathogens chosen for antibacterial study, two Gram-negative bacterial strains, Escherichia coli O157:H7 (TWC 01) and Salmonella enteritidis SE 01, were obtained from clinical patients in Taiwan, and two Grampositive bacterial strains, Bacillus subtilis (ATCC 27689) and Staphylococcus aureus (ATCC 10832) were obtained from the American Type Culture Collection (Manassas, VA, USA). L. plantarum TW10, a probiotic bacterium cocultured with each test bacteria for assessing a possible synergistic antibacterial effect with synthesized NPs, was isolated from Taiwanese pickled cabbage. Microbiological media, ie, tryptic soy broth and Lactobacilli MRS (Man-Rogosa-Sharpe) broth were sourced from Difco (Detroit, MI, USA). Commercial antibiotics (ampicillin and vancomycin) were purchased from Sigma-Aldrich. A Shel Lab incubator (model 1535, Sheldon Manufacturing Inc, Cornelius, OR, USA) was used to incubate the NPs with bacterial cells. The bacterial concentration was measured as a function of optical density at $600 \mathrm{~nm}$ using an ELISA reader from Thermo Fisher Scientific (Waltham, MA, USA). The optical density was calibrated using McFarland turbidity standard number 0.5 obtained from bioMérieux Clinical Diagnostics (March L'Étoile, France).

\section{Synthesis of $\mathrm{CeO}_{2} \mathrm{NPs}$}

$\mathrm{CeO}_{2}$ NPs were synthesized by a combustion method with glycine as an oxidizer based on simple propellant chemistry. The stoichiometric amounts of cerium nitrate and glycine as shown below (Eq. 1) were dissolved in double-distilled water and mixed until a transparent solution was obtained. The mixture was kept over a hot plate for combustion and the resulting NPs were then centrifuged at 5,000 rpm for 30 minutes, followed by washing with double-distilled water three times to remove any unreacted nitrate and glycine, and drying in an oven overnight to obtain a pale yellow-colored product.

$$
\begin{gathered}
18 \mathrm{Ce}\left(\mathrm{NO}_{3}\right)_{3} \cdot 6 \mathrm{H}_{2} \mathrm{O}+30 \mathrm{NH}_{2} \mathrm{CH}_{2} \mathrm{COOH} \stackrel{\Delta}{\rightarrow} 18 \mathrm{CeO} \mathrm{O}_{2} \\
+60 \mathrm{CO}_{2} \uparrow+42 \mathrm{~N}_{2} \uparrow+183 \mathrm{H}_{2} \mathrm{O} \uparrow
\end{gathered}
$$

\section{Synthesis of Au NPs}

$\mathrm{Au}$ NPs were synthesized by the reduction of $\mathrm{Au}$ salt with sodium borohydride. $\mathrm{NaBH}_{4}$ solution was added dropwise to $0.5 \mathrm{~g}$ of $\mathrm{HAuCl}_{4}$ in water to maintain a molar ratio of $\mathrm{HAuCl}_{4}: \mathrm{NaBH}_{4}$ at 1:0.43 with stirring for 4 hours. The resulting suspension was then centrifuged at 7,000 rpm for 30 minutes, washed three times with double-distilled water, and dried in an oven at $100^{\circ} \mathrm{C}$ for 12 hours to obtain Au NPs.

\section{Synthesis of Au-impregnated $\mathrm{CeO}_{2} \mathrm{NPs}$}

$\mathrm{Au}$ NPs were impregnated onto the surface of $\mathrm{CeO}_{2} \mathrm{NPs}$ using a deposition-precipitation method. First, $0.06 \mathrm{~g}$ of $\mathrm{HAuCl}_{4}$ was added to $1 \mathrm{~g}$ of $\mathrm{CeO}_{2} \mathrm{NPs}$ in water and the solution was stirred and heated at $100^{\circ} \mathrm{C}$ until a dry powder was formed. The powder obtained was then redispersed in distilled water and $\mathrm{NaBH}_{4}$ solution (molar ratio of $\mathrm{HAuCl}_{4}: \mathrm{NaBH}_{4}$ at 1:0.43) was added dropwise to obtain a purple-colored precipitate, which was centrifuged, washed three times with doubledistilled water, and dried in a hot air oven overnight to obtain $\mathrm{CeO}_{2}$ NPs coated with $3.5 \% \mathrm{Au}$.

\section{Characterization of NPs}

$\mathrm{X}$-ray diffraction studies were performed in a diffractometer (Ultima IV, Rigaku Corporation, The Woodlands, TX, USA) using $\mathrm{Cu} \mathrm{K}_{\alpha}$ radiation with a scanning rate of $2^{\circ}$ per minute and a step size of $0.02^{\circ}$ for $\mathrm{CeO}_{2}, \mathrm{Au} / \mathrm{CeO}_{2}$, and $\mathrm{Au}$ NPs in the $2 \theta$ range of $25^{\circ}-40^{\circ}$. Particle size was determined by the Scherrer's equation (Eq. 2) assuming a Gaussian shape for the peaks.

$$
d=k \lambda \mid \beta \cos \theta
$$

where $d$ is the mean crystallite size $(\mathrm{nm}), k$ is Scherrer's constant (0.9), $\beta$ is the full width half maximum, and $\theta$ is the diffraction angle.

Structural analysis was carried out using scanning electron microscopy (SEM; model S-3400N, Hitachi, Tokyo, Japan). Electron microscopic images were recorded after coating the sample with carbon. Energy dispersive X-ray analysis was carried out for identification as well as quantification of $\mathrm{Au}$ on the surface of the $\mathrm{CeO}_{2}$ NPs. Both particle size and the surface morphology of the samples obtained were imaged by transmission electron microscopy (model JEM 2100F, JEOL Ltd, Tokyo, Japan). The samples were prepared by dropping a diluted solution of each nanoparticle type on a 150-mesh copper TEM grid (Ted Pella Inc, Redding, CA, USA) and vacuum-drying for one hour. Optical studies of the NPs obtained were carried out using an ultraviolet-visible spectrophotometer (model Lambda 650S, Perkin Elmer, Boston, MA, USA) in the scan range of 300-700 nm, with data collection at a resolution of $1 \mathrm{~nm}$. Surface charge measurements for $\mathrm{CeO}_{2} \mathrm{NPs}$ and $\mathrm{Au} / \mathrm{CeO}_{2}$ NPs were carried out using a nanoparticle analyzer (model SZ-100, Horiba, Kyoto, Japan). The study samples were prepared by dispersing the NPs in double-distilled water at a 
concentration of $1 \mathrm{mg} / \mathrm{mL}$ and monitoring at regular intervals over a period of 48 hours.

\section{Cytotoxicity study}

Normal RAW 264.7 macrophage cells were cultured in DMEM containing 10\% fetal bovine serum, $100 \mathrm{U} / \mathrm{mL}$ penicillin, and $100 \mu \mathrm{g} / \mathrm{mL}$ streptomycin, while the A549 human lung cancer cells were cultured in RPMI-1640 medium containing 5\% fetal bovine serum, $100 \mathrm{U} / \mathrm{mL}$ penicillin, and $100 \mu \mathrm{g} / \mathrm{mL}$ streptomycin. The cultured cells were then incubated at $37^{\circ} \mathrm{C}$ under $90 \%$ humidity and $5 \%$ $\mathrm{CO}_{2}$ for 2-3 days. When cell density had reached $80 \%$ confluence, the cells were washed twice with phosphatebuffered saline ( $\mathrm{pH} 7.4$ ), and $1 \mathrm{~mL}$ of $0.05 \%$ trypsinethylenediaminetetraacetic acid was added, followed by shaking for a few minutes. The cells were then viewed under the microscope. Next, fresh medium was added to neutralize and harvest the cells, followed by centrifugation at 1,000 rpm for 5 minutes. Fresh medium was then added again to the supernatant for cell suspension, mixed with $10 \mathrm{~mL}$ of culture medium, and $0.2 \mathrm{~mL}$ of cell suspension was collected for MTT assay.

The cytotoxicity of $\mathrm{Au} \mathrm{NPs}, \mathrm{CeO}_{2} \mathrm{NPs}$, and $\mathrm{Au} / \mathrm{CeO}_{2}$ NPs was determined by seeding $0.2 \mathrm{~mL}$ of cell suspension in a 96-well plate with each well containing $1.5 \times 10^{4}$ RAW 264.7 cells or 4,000 A549 cells. After incubation for 24 or 48 hours to enable attachment of cells to the bottom, the medium in the wells was replaced with fresh medium containing nine different concentrations of each type of nanoparticle $(0.001,0.01,0.1,1.0,10,50,100,500$, and $1,000 \mu \mathrm{M})$ and incubated for 24 or 48 hours. The medium was then removed and $180 \mu \mathrm{L}$ of reagent mixture containing MTT $(5 \mathrm{mg} / \mathrm{mL}$ in phosphate-buffered saline) and Hank's Balanced Salt Solution at a ratio of $1: 9(\mathrm{v} / \mathrm{v})$ was added to each well. The well plate was then incubated for another 4 hours at $37^{\circ} \mathrm{C}$ and $5 \%$ $\mathrm{CO}_{2}$ to allow exponential cell growth. Upon incubating with the MTT reagent mixture, the tetrazolium ring in MTT was cleaved by mitochondrial dehydrogenase in metabolically active cells and eventually the pale yellow water-soluble tetrazolium salt was changed into a purple water-insoluble formazan derivative. The MTT solution was then removed and total mitochondrial activity was determined by dissolving the formazan crystals in $150 \mu \mathrm{L}$ of dimethyl sulfoxide followed by shaking for 15 minutes and measuring the absorbance at $570 \mathrm{~nm}$ using an ELISA reader. Prior to measurement of absorbance, the plate reader was calibrated to zero using culture medium without cells. The relative cell viability in a percentage compared with the control wells was calculated using the formula: $[\mathrm{ABS}]_{\mathrm{NP}} /[\mathrm{ABS}]_{\mathrm{CTL}} \times 100$, where $[\mathrm{ABS}]_{\mathrm{CTL}}$ and $[\mathrm{ABS}]_{\mathrm{NP}}$ denote absorbance measured in wells without and with NPs, respectively. To reduce artifacts arising from background MTT absorbance, the percentage cell viability data were obtained by subtracting the background absorbance at $690 \mathrm{~nm}$ from the test absorbance measurement at $570 \mathrm{~nm}$.

\section{Intracellular ROS production and uptake of NPs by cells}

The formation of intracellular ROS was determined by measuring the oxidative transformation of the nonfluorescent reagent, CM-H $\mathrm{H}_{2}$ CFDA, to a highly fluorescent compound, ie, dichlorofluorescein. Initially, cells were seeded in a 96-well plate at a density of $2 \times 10^{3}$ cells per well in $100 \mu \mathrm{L}$ of medium. After 24 hours of incubation at $37^{\circ} \mathrm{C}$ and $5 \% \mathrm{CO}_{2}$, the cells were treated separately with various concentrations $(0.001,0.01,0.1,1,10,50,100,500$, and $1,000 \mu \mathrm{g} / \mathrm{mL}$ ) of $\mathrm{CeO}_{2} \mathrm{NPs}$ and $\mathrm{Au} / \mathrm{CeO}_{2} \mathrm{NPs}$ for 24 or 48 hours, washed three times with phosphate-buffered saline, and incubated with $10 \mu \mathrm{M}$ CM-H ${ }_{2}$ DCFDA for one hour at $37^{\circ} \mathrm{C}$. The cells were then washed, and dichlorofluorescein was measured immediately using a microplate spectrofluorometer at an excitation and emission wavelength of $490 \mathrm{~nm}$ and $545 \mathrm{~nm}$, respectively, with cells not exposed to NPs used as the control.

For the cellular uptake study, A549 human lung cancer cells were incubated with $\mathrm{CeO}_{2} \mathrm{NPs}$ or $\mathrm{Au} / \mathrm{CeO}_{2} \mathrm{NPs}$ for 48 hours. After incubation, a portion of the cells was collected in a tube, centrifuged at 1,000 rpm for 10 minutes, and washed twice with phosphate-buffered saline. Next, $1.5 \mathrm{~mL}$ of $4 \%$ paraformaldehyde and $2.5 \%$ glutaraldehyde was added to fix the cells, followed by post-fixing with $1 \%$ osmium tetroxide, washing three times with phosphatebuffered saline, and sequentially washing with 30\%, 50\%, $70 \%, 90 \%$, and $100 \%$ alcohol as well as $100 \%$ acetone for dehydration. The cell pellet was further treated with different ratios $(3: 1,1: 1,1: 3,0: 1)$ of $100 \%$ acetone/Spurr's resin for 2 hours each and polymerized in an oven for cutting of an ultrathin section, which was then mounted on a carbon-coated grid for recording of TEM images.

\section{Antibacterial study}

The antibacterial activity of freshly prepared $\mathrm{Au} \mathrm{NPs}_{\mathrm{s}} \mathrm{CeO}_{2}$ $\mathrm{NPs}$, and $\mathrm{Au} / \mathrm{CeO}_{2}$ NPs along with commercial antibiotics, ie, ampicillin and vancomycin, was evaluated against four selected pathogens, ie, E. coli O157:H7 (TWC 01), S. enteritidis SE 01, B. subtilis (ATCC 27689), and S. aureus 
(ATCC 10832) by microbroth dilution tests. After an initial 20-minute thawing of frozen bacterial strains in ice, the test bacteria was subcultured aerobically in $5 \mathrm{~mL}$ of tryptic soy broth overnight, followed by centrifugation at $5,000 \mathrm{~g}$ for 10 minutes and suspension of the pellet in $10 \mathrm{~mL}$ of phosphatebuffered saline ( $\mathrm{pH}$ 7.2). The optical density of each bacterial suspension was then adjusted to obtain $10^{8}$ colony forming units (CFU)/mL by using McFarland turbidity standard number 0.5 . From the stock solution of each nanoparticle type, nine different concentrations of $6,12,23,47,93,186$, 372,744 , and $1,488 \mu \mathrm{M}$ were prepared in bacterial suspension at $10^{8} \mathrm{CFU} / \mathrm{mL}$. Likewise, the same concentrations were prepared separately for the commercial antibiotics, ampicillin and vancomycin. Subsequently, $200 \mu \mathrm{L}$ of each concentration was put into a polystyrene tray containing 96 wells so that each well contained a bacterial concentration of $2 \times 10^{7} \mathrm{CFU} / \mathrm{mL}$. The bacterial inoculum containing NPs was then incubated at $37^{\circ} \mathrm{C}$ for 16 hours. After incubation, the optical density of each well was determined at $600 \mathrm{~nm}$ using an ELISA reader. Optical density-concentration curves were obtained for relative comparison of bacterial inhibition as a function of NP/antibiotic concentration. For antibacterial activity in the test bacteria cocultured with $L$. plantarum TW10, a 50:50 (v/v) ratio of L. plantarum to each test bacteria was prepared after subculturing in Lactobacilli MRS broth and tryptic soy broth, respectively. The bacterial concentration was then adjusted to $10^{8} \mathrm{CFU} / \mathrm{mL}$, and the remaining procedure was the same as described above.

\section{Precautions against endotoxin contamination}

Care was taken to exclude the potential influence of endotoxin on the observed outcomes of the cytotoxicity and antibacterial experiments. Given that water is the most common source of endotoxin contamination in the laboratory, ultrapure water from a Millipore filtration system was used for all antibacterial experiments. Further, before use, all glasswares were washed thoroughly with warm water after soaking overnight in a $1 \%$ solution of alkaline detergent and autoclaving. We also used nitrile gloves and carried out all experiments in a laminar flow hood to avoid any potential influence of endotoxin on the observed cytotoxicity and antibacterial activity.

\section{Results and discussion $X$-ray diffraction}

Figure 1 shows the X-ray diffraction patterns for the Au NPs, $\mathrm{CeO}_{2} \mathrm{NPs}$, and $\mathrm{Au} / \mathrm{CeO}_{2} \mathrm{NPs}$. The spectra obtained matched

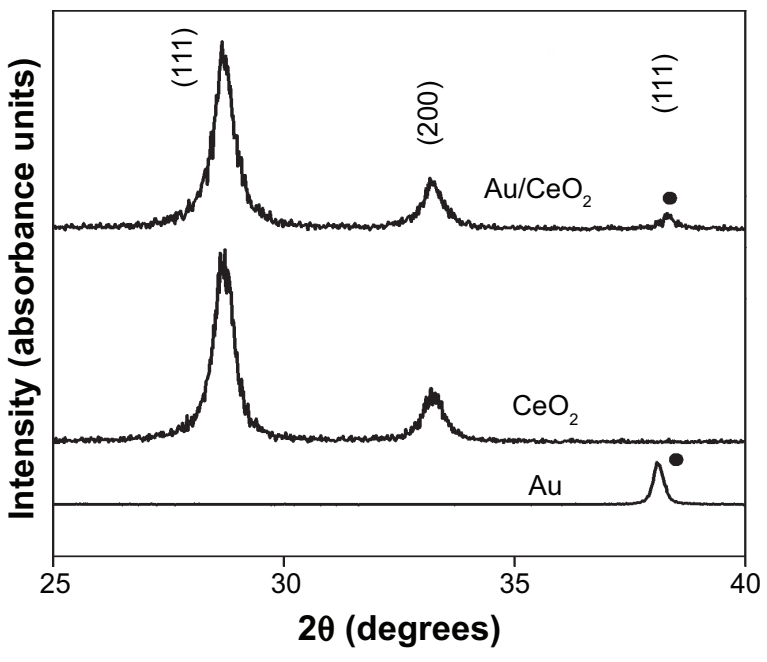

Figure I X-ray diffraction pattern for the as-prepared nanoparticles. Note: $\bullet$ indicates Au.

Abbreviations: $\mathrm{Au}$, gold; $\mathrm{CeO}_{2}$, cerium oxide.

the International Centre for Diffraction Data card number, ie, 01-073-6318 and 03-065-2870 for the cubic fluorite structure of $\mathrm{CeO}_{2}$ NPs and the cubic structure of Au NPs, respectively. A broader peak corresponded to formation of NPs, and the average crystallite size of the $\mathrm{CeO}_{2}$ NPs was found to be $9.3 \mathrm{~nm}$ from the Scherrer's formula. However, for $\mathrm{Au} / \mathrm{CeO}_{2} \mathrm{NPs}$, a weak and low intensity peak appeared, which corresponded to a (111) reflection plane (Figure 1). Consequently, the particle size for the $\mathrm{Au}$ in the $\mathrm{Au} / \mathrm{CeO}_{2}$ NPs could not be obtained by calculation..$^{22}$ In addition, the difficulty in identification and quantitative measurement of size was due to formation of fine and highly dispersed $\mathrm{Au}$ NPs on $\mathrm{CeO}_{2}$ surface during $\mathrm{Au}$ deposition carried out by impregnation method.

\section{Scanning electron microscopy}

The SEM images for $\mathrm{CeO}_{2} \mathrm{NPs}$ and $\mathrm{Au} / \mathrm{CeO}_{2} \mathrm{NPs}$ in Figure 2A and $\mathrm{B}$ depict a sponge-like porous network structure for the $\mathrm{CeO}_{2}$ particles. The sponge-like structure observed on the SEM images is mainly due to the large volume of gas released during the combustion process involved in the synthesis of $\mathrm{CeO}_{2}$ NPs. Fundamentally, a typical combustion process involves a reaction between fuel and an oxidizer, resulting in generation of gas (as shown in Eq. 1), which eventually escapes to the nanoparticle surface, creating a network structure with high porosity. Upon impregnation, a fine dispersion of Au along with a few Au agglomerates occurred, as shown by bright white spots in Figure 2B. In addition, the presence of well dispersed Au NPs identified on SEM images was consistent with the X-ray diffraction results. Figure $2 \mathrm{C}$ and $\mathrm{D}$ shows the energy dispersive $\mathrm{X}$-ray 

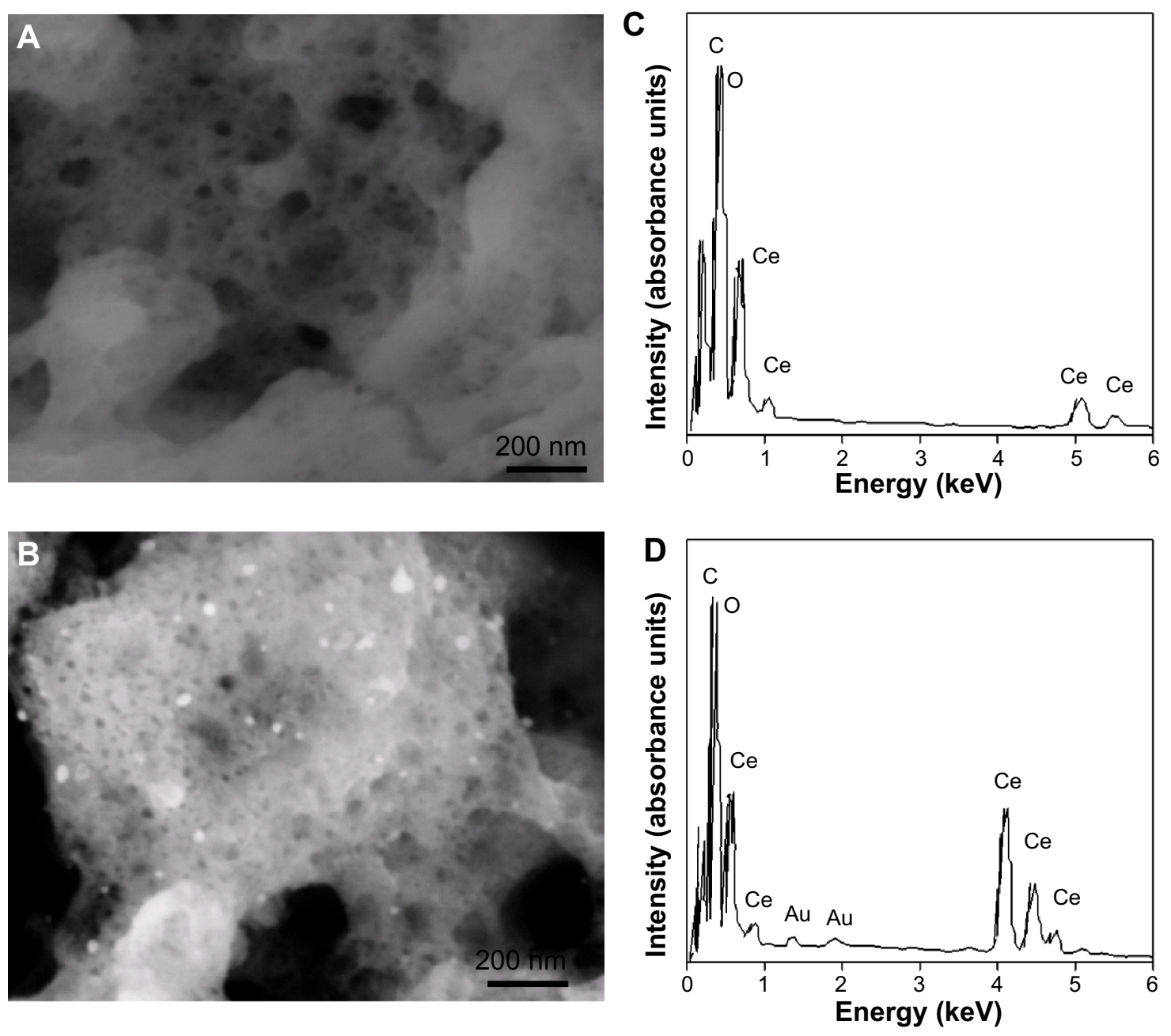

Figure 2 Scanning electron microscopic images of $\mathrm{CeO}_{2} \mathrm{NPs}(\mathbf{A})$ and $\mathrm{Au} / \mathrm{CeO}_{2} \mathrm{NPs}(\mathbf{B})$ along with their corresponding energy dispersive $\mathrm{X}$-ray spectra (C, D). Abbreviations: $\mathrm{Au}$, gold; $\mathrm{Ce}$, cerium oxide; $\mathrm{CeO}_{2}$, cerium oxide; $\mathrm{Au} / \mathrm{CeO}_{2}$, gold-coated cerium oxide.

spectra for the $\mathrm{CeO}_{2}-\mathrm{NPs}$ and $\mathrm{Au} / \mathrm{CeO}_{2} \mathrm{NPs}$, respectively. The presence of Au peaks in Figure 2D confirmed incorporation of $\mathrm{Au}$ in the $\mathrm{Au} / \mathrm{CeO}_{2} \mathrm{NPs}$. The energy dispersive X-ray spectra also revealed deposition of a 3.26 weight percentage of $\mathrm{Au}$ on the $\mathrm{CeO}_{2}$ surface, and the observed drop in percentage Au loading compared with actual loading may reflect leaching of weakly bound Au NPs from the surface of the $\mathrm{CeO}_{2}$ NPs during the several washing steps involved in their synthesis.

\section{Transmission electron microscopy}

The TEM images for $\mathrm{CeO}_{2}, \mathrm{Au} / \mathrm{CeO}_{2}$, and Au NPs are shown in Figure 3A-C. A network-based structure was observed for $\mathrm{CeO}_{2}$ which can be attributed to the typical nature of the synthesis process. This network structure was mainly due to the large volume of gas released during formation of the NPs by a combustion process, as shown in the SEM images described above. Upon impregnation, Au NPs were deposited on the surface of the $\mathrm{CeO}_{2} \mathrm{NPs}$, which showed a nearly spherical shape and the average particle size of the $\mathrm{CeO}_{2} \mathrm{NPs}$ was found to be $9.7 \mathrm{~nm}$. In spite of its wider size distribution, the average Au size was calculated to be less than $5 \mathrm{~nm}$. When $\mathrm{Au}$ was prepared in the absence of $\mathrm{CeO}_{2}$ NPs, the observed Au NP size was found to be higher $(>15$ $\mathrm{nm}$ ), indicating the significant role of the $\mathrm{CeO}_{2} \mathrm{NP}$ surface as a support for Au NPs.

\section{Ultraviolet-visible spectroscopy}

Figure 3D shows the ultraviolet-visible spectra for $\mathrm{CeO}_{2}$ and $\mathrm{Au} / \mathrm{CeO}_{2} \mathrm{NPs}$, with an inset depicting an enlarged view of the $\mathrm{Au}$ peak for $\mathrm{Au}$ NPs. $\mathrm{As} \mathrm{CeO}_{2}$ absorbs strongly in the ultraviolet region, broad absorption of $\mathrm{Au} / \mathrm{CeO}_{2}$ starting from $430 \mathrm{~nm}$ was observed, which was mainly due to the charge transfer transition between the $\mathrm{O} 2 \mathrm{p}$ and $\mathrm{Ce} 4 \mathrm{f}$ bands. ${ }^{23}$ 

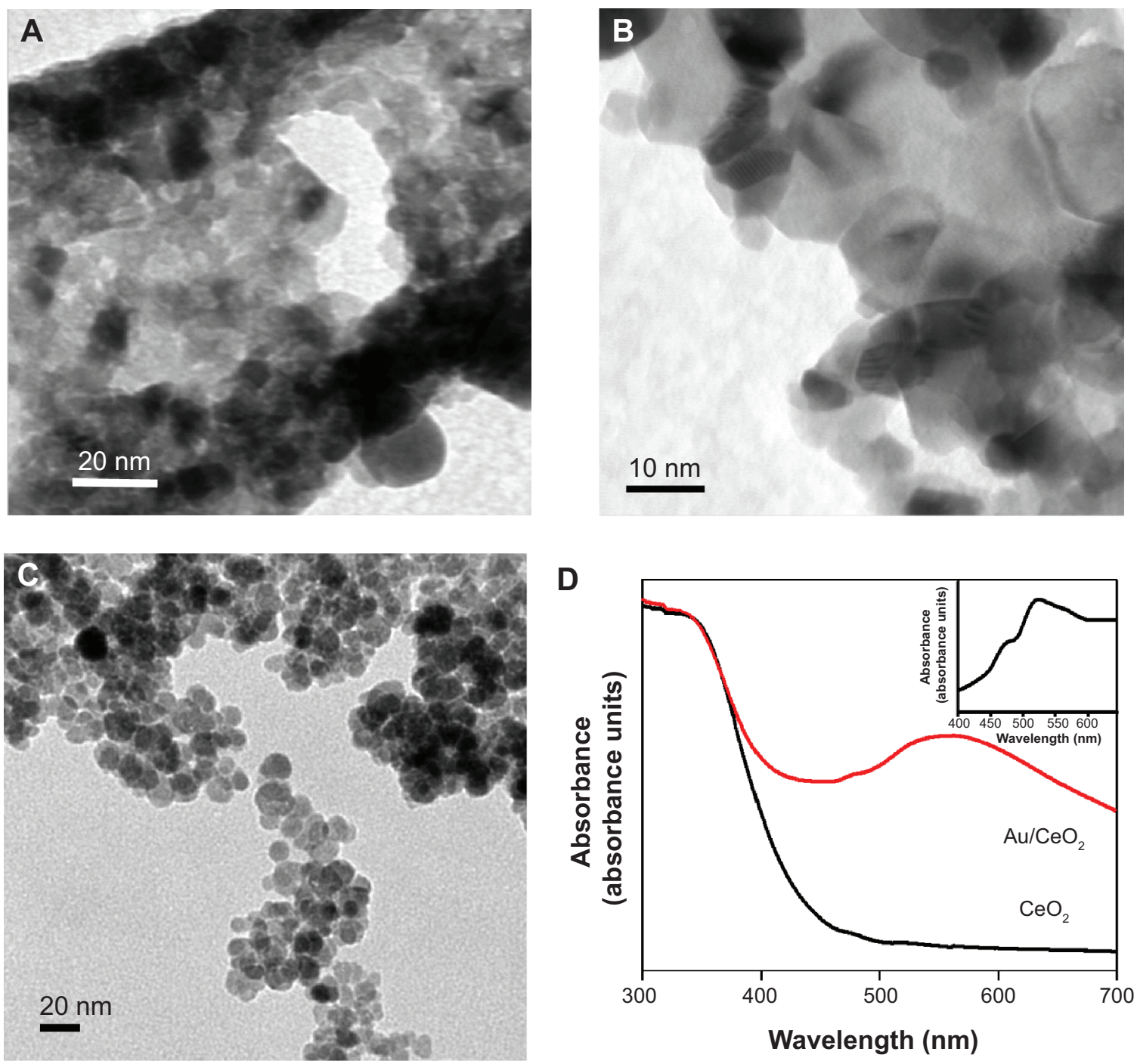

Figure 3 Transmission electron microscopic image of $\mathrm{CeO}_{2}(\mathbf{A}), \mathrm{Au} / \mathrm{CeO}_{2}(\mathbf{B}), \mathrm{Au} \mathrm{NPs}(\mathbf{C})$, and ultraviolet-visible spectra for $\mathrm{CeO}$, and $\mathrm{Au} / \mathrm{CeO}$ (D) with an inset showing an enlarged view of the Au peak for Au NPs.

Abbreviations: $\mathrm{Au}$, gold; $\mathrm{CeO}_{2}$, cerium oxide; $\mathrm{Au} / \mathrm{CeO}_{2}$, gold-coated cerium oxide; NPs, nanoparticles.

Cerium in $\mathrm{CeO}_{2}$ NPs exists in two oxidation states, namely +3 and +4 , exhibiting a characteristic absorption band at 253 $\mathrm{nm}$ and $270-340 \mathrm{~nm}$, respectively. ${ }^{24}$ Pure Au NPs showed a localized surface plasmon resonance (LSPR) band around $522 \mathrm{~nm}$. However, upon coating of Au NPs on the surface of $\mathrm{CeO}_{2} \mathrm{NPs}$, a new absorption band appeared at $567 \mathrm{~nm}$, which corresponded to the LSPR of the Au NPs. ${ }^{25}$ Obviously, the bare $\mathrm{CeO}_{2}$ NPs did not show any LSPR and thus formation of the new band in $\mathrm{Au} / \mathrm{CeO}_{2} \mathrm{NPs}$ should be due to the LSPR of the Au NPs. Moreover, the LSPR band for Au NPs $(522 \mathrm{~nm})$ and $\mathrm{Au} / \mathrm{CeO}_{2} \mathrm{NPs}(567 \mathrm{~nm})$ appeared at different wavelengths due to variation in the refractive indices between $\mathrm{CeO}_{2}$ (2.2) and $\mathrm{Au}$ (0.47) NPs, which is consistent with the observation made by Zhu et al. ${ }^{26}$ Although a sharp surface plasmon peak is expected for Au NPs, a broader absorption peak appeared, owing to the absence of capping agent.

\section{Cytotoxicity of $\mathrm{Au}, \mathrm{CeO}_{2}$, and $\mathrm{Au} / \mathrm{CeO}_{2} \mathrm{NPs}$}

To investigate the therapeutic application of the synthesized NPs, the cytotoxicity of $\mathrm{Au}, \mathrm{CeO}_{2}$, and $\mathrm{Au} / \mathrm{CeO}_{2} \mathrm{NPs}$ was evaluated by performing cell viability tests against normal RAW 264.7 macrophage cells and A549 human adenocarcinoma epithelial cells by MTT assay. In this study, a human lung cancer cell line was chosen because lung cancer is the leading cause of cancer deaths in Taiwan, while RAW 264.7 macrophages are widely used as a classic positive control representing normal cells and as a model cell line to represent 

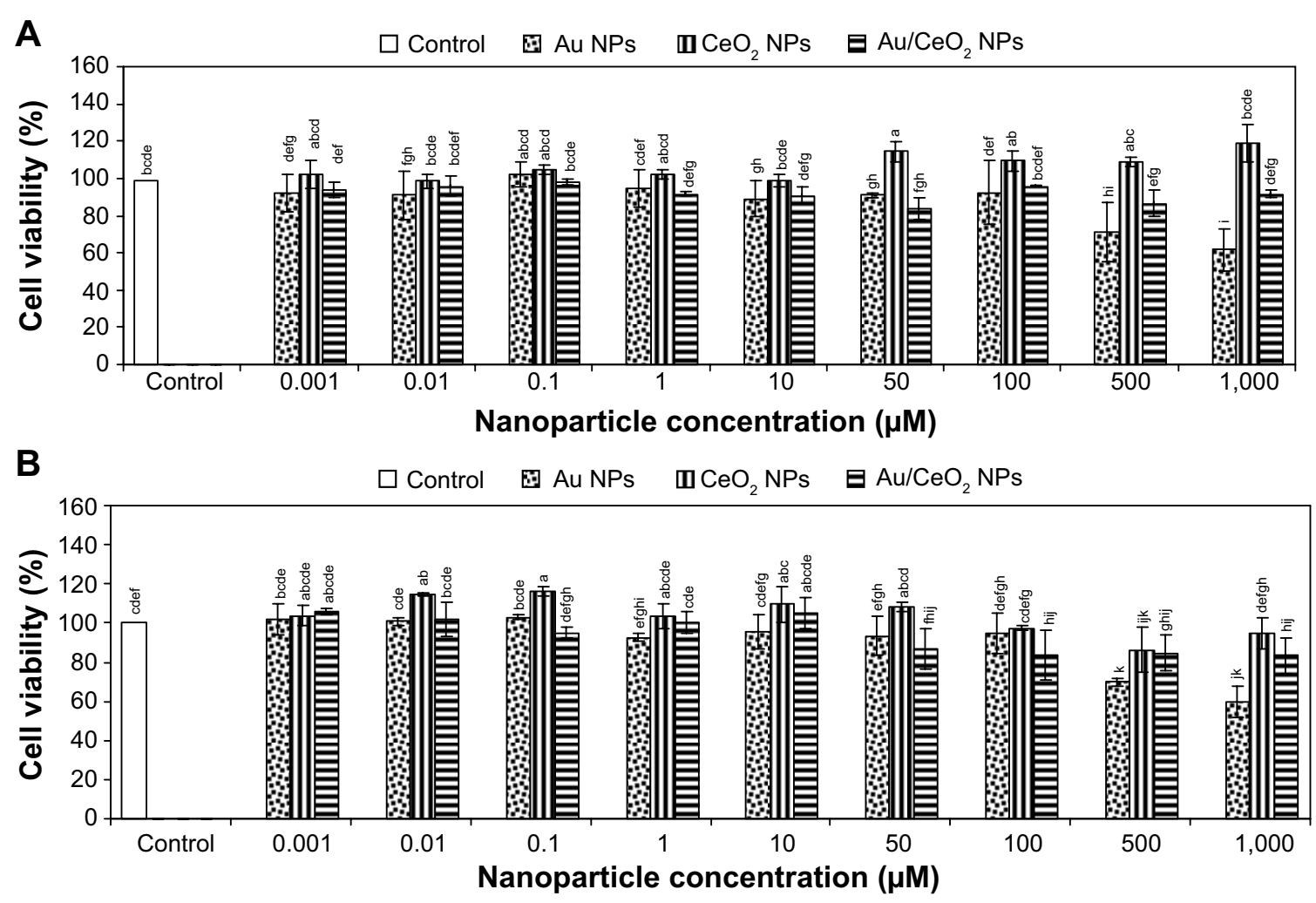

Figure 4 Viability of RAW 264.7 normal macrophage cells as affected by Au NPs, $\mathrm{CeO}_{2} \mathrm{NPs}$, and Au/CeO $\mathrm{NPs}_{2}$ after 24 hours $(\mathbf{A})$ and 48 hours (B) of incubation. Superscripted alphabetical letters indicate statistically significant values $(P<0.05)$.

Abbreviations: $\mathrm{Au}$, gold; $\mathrm{CeO}_{2}$, cerium oxide; $\mathrm{Au} / \mathrm{CeO}_{2}$, gold-coated cerium oxide; NPs, nanoparticles.

osteoclasts. After incubating the NP-spiked cell culture for 24 or 48 hours, percentage cell viability was determined by measuring the cell survival rate relative to that of the control. Treatment of RAW 264.7 cells with $\mathrm{CeO}_{2} \mathrm{NPs}$ for 24 and 48 hours and with $\mathrm{Au} / \mathrm{CeO}_{2} \mathrm{NPs}$ for 24 hours did not show any significant toxicity at any of the doses studied (0.001-1,000 $\mu \mathrm{M}$, Figure 4). However, after 48 hours of treatment with $\mathrm{Au} / \mathrm{CeO}_{2} \mathrm{NPs}$, a $13 \%-17 \%$ decrease in cell viability was observed at higher doses $(50-1,000 \mu \mathrm{M})$, but no significant decline at a dose $\leq 10 \mu \mathrm{M}$. On the other hand, $\mathrm{Au}$ NPs at doses of 500 and $1,000 \mu \mathrm{M}$ showed relatively greater toxicity towards RAW 264.7 cells, with the cell viability decreasing by $28.2 \%$ and $30.2 \%$, respectively, after 24 hours of treatment, and by $37.8 \%$ and $40.3 \%$ after 48 hours of treatment, respectively (Figure 4). For A549 lung cancer cells, no significant toxicity occurred at $\mathrm{Au} \mathrm{NP}$ and $\mathrm{CeO}_{2} \mathrm{NP}$ doses $\leq 100 \mu \mathrm{M}$, or for $\mathrm{Au} / \mathrm{CeO}_{2} \mathrm{NP}$ doses $\leq 50 \mu \mathrm{M}$ after 24 hours of treatment. However, by increasing the NP dose to 500 or $1,000 \mu \mathrm{M}$, the cell viability decreased to $86.6 \%$ and $76.9 \%$ for $\mathrm{Au}$ NPs, to $90.6 \%$ and $85.4 \%$ for $\mathrm{CeO}_{2} \mathrm{NPs}$, and to $81.1 \%$ and $70.6 \%$ for $\mathrm{Au} / \mathrm{CeO}_{2} \mathrm{NPs}$, respectively (Figure 5). In addition, $\mathrm{Au} / \mathrm{CeO}_{2} \mathrm{NPs}$ resulted in a $12 \%$ decrease in cell viability even at a dose of $100 \mu \mathrm{M}$ over a 24-hour incubation period. After prolonged incubation for 48 hours, the cytotoxicity towards A549 cells increased substantially for all the NPs, with $\mathrm{Au} / \mathrm{CeO}_{2} \mathrm{NPs}$ showing the strongest inhibitory effect, ie, $31.4 \%, 41.9 \%$, and $51.0 \%$ for 100,500 , and $1,000 \mu \mathrm{M}$, respectively. Interestingly, both $\mathrm{Au}$ NPs and $\mathrm{CeO}_{2}$ NPs showed a similar inhibition at $500 \mu \mathrm{M}$ (27.8\% and $28.3 \%)$ and $1,000 \mu \mathrm{M}(42.0 \%$ and $40.0 \%$, Figure 5). The $\mathrm{IC}_{50}$ value was not determined because the inhibitory effect did not exceed $50 \%$ for any of the three types of NPs in the dose range tested $(0.001-1,000 \mu \mathrm{M})$, with the exception of $\mathrm{Au} / \mathrm{CeO}_{2} \mathrm{NPs}$ at $1,000 \mu \mathrm{M}$.

Owing to their unique electronic properties, $\mathrm{CeO}_{2} \mathrm{NPs}$ have an inherent tendency to exist in mixed valence states $\left(\mathrm{Ce}^{3+}\right.$ and $\left.\mathrm{Ce}^{4+}\right)$ and switch between two different oxidation states via an oxidation-reduction cycle, thereby conferring antioxidant activity to these NPs. ${ }^{5,27}$ These dual oxidation states are mainly due to existing oxygen vacancies or defects created by the loss of oxygen and eventual reduction of $\mathrm{Ce}^{4+}$ to $\mathrm{Ce}^{3+}$. In the presence of $\mathrm{ROS}, \mathrm{Ce}^{3+}$ undergoes oxidation initially and an autoregenerative mechanism reverts the oxidation state from $\mathrm{Ce}^{4+}$ back to $\mathrm{Ce}^{3+}$, thereby perpetuating the free radical scavenging activity. ${ }^{5,27}$ Moreover, it has been shown that $\mathrm{CeO}_{2} \mathrm{NPs}$ are capable of mimicking superoxide 

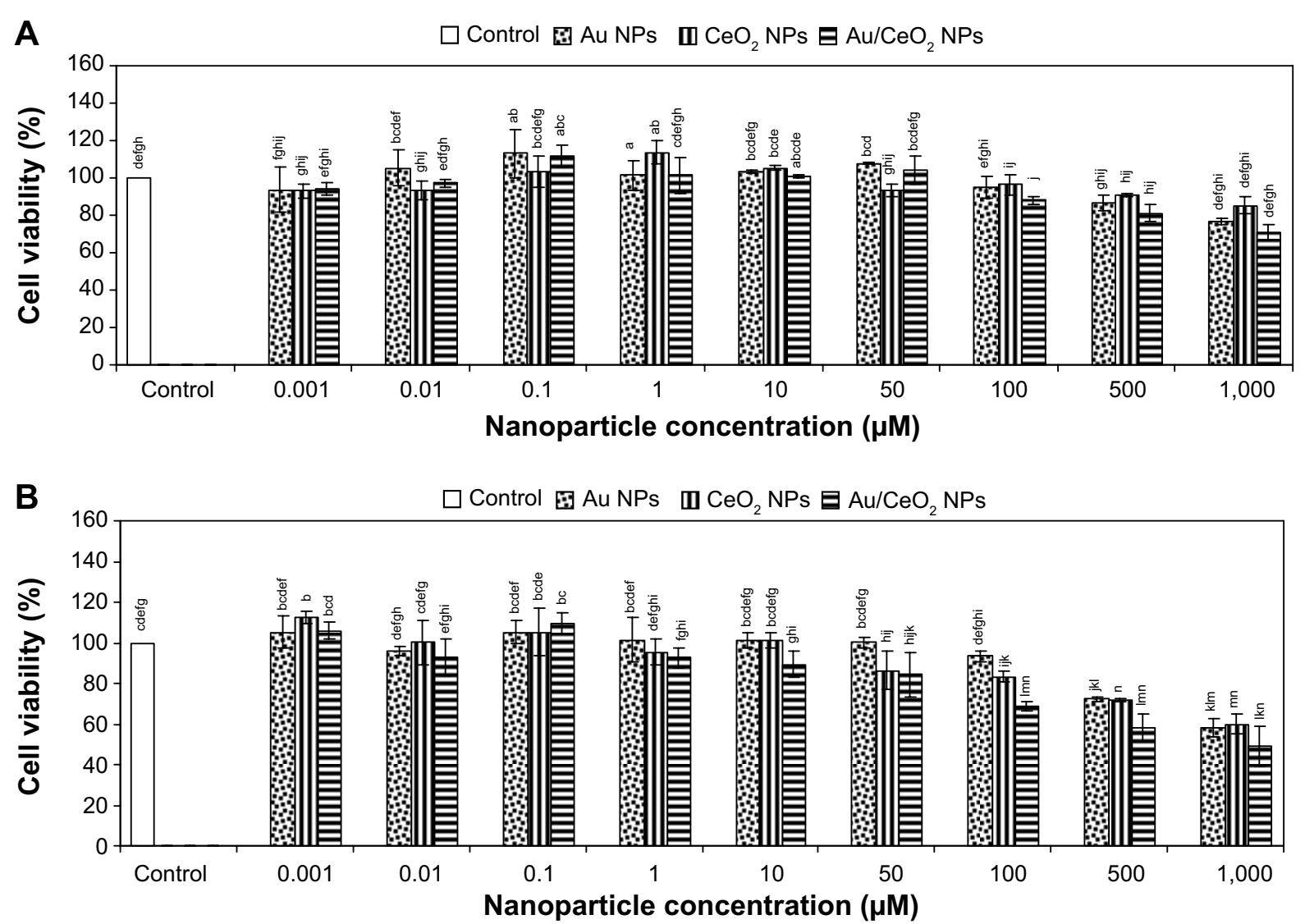

Figure 5 Viability of $\mathrm{A} 549$ human lung adenocarcinoma epithelial cells as affected by Au NPs, $\mathrm{CeO}_{2} \mathrm{NPs}$, and $\mathrm{Au} / \mathrm{CeO}_{2} \mathrm{NPs}$ after 24 hours $(\mathbf{A})$ and 48 hours (B) of incubation. Superscripted alphabetical letters indicate statistically significant values $(P<0.05)$.

Abbreviations: $\mathrm{Au}$, gold; $\mathrm{CeO}_{2}$, cerium oxide; $\mathrm{Au} / \mathrm{CeO}_{2}$, gold-coated cerium oxide; NPs, nanoparticles.

dismutase activity with a catalytic rate constant exceeding that of a biological enzyme. ${ }^{28}$ These inherent material properties confer $\mathrm{CeO}_{2} \mathrm{NPs}$ with well demonstrated cytoprotective ability in various normal mammalian or human cells. In several reports, $\mathrm{CeO}_{2} \mathrm{NPs}$ have been shown to be nontoxic to murine insulinoma $\beta$ TC-tet cells, ${ }^{29}$ human umbilical vein endothelial cells and human lung fibroblasts, ${ }^{30}$ RAW 264.7 macrophage cells, ${ }^{27}$ human breast epithelial cells,${ }^{31}$ murine macrophages, ${ }^{32}$ and human colon cells. ${ }^{33}$ In contrast, several studies have demonstrated a cytotoxic effect of $\mathrm{CeO}_{2} \mathrm{NPs}$ in normal cells, including human dermal fibroblasts ${ }^{5}$ and human peripheral blood monocytes, ${ }^{34}$ which was attributed to oxidative stress in the former and mitochondrial damage along with overexpression of apoptosis-inducing factor in the latter. In our study, $\mathrm{Au} / \mathrm{CeO}_{2} \mathrm{NPs}$ showed minimal toxicity $(\sim 15 \%-17 \%)$ towards normal RAW 264.7 macrophage cells (Figure 4), and thus $\mathrm{CeO}_{2} \mathrm{NPs}$ and $\mathrm{Au} / \mathrm{CeO}_{2} \mathrm{NPs}$ can be deemed nontoxic because materials with cell viability $>80 \%$ are usually considered cytocompatible..$^{35}$ Based on the above discussion, both $\mathrm{CeO}_{2} \mathrm{NPs}$ and $\mathrm{Au} / \mathrm{CeO}_{2} \mathrm{NPs}$ appear to protect RAW 264.7 cells by scavenging ROS and reducing oxidative stress after becoming localized inside the cells. In a toxicity study comparing three metal oxide NPs $\left(\mathrm{CeO}_{2}, \mathrm{TiO}_{2}\right.$, and $\left.\mathrm{ZnO}\right)$, Xia et $\mathrm{al}^{27}$ observed internalization of $\mathrm{CeO}_{2}$ NPs through LAMP-1-positive endosomal compartments in RAW 264.7 cells, suppression of ROS, and induction of cellular resistance to exogenous sources of oxidative stress. Hirst et $\mathrm{al}^{32}$ also demonstrated the protective effects of $\mathrm{CeO}_{2}$ NPs in J774A.1 murine macrophages in vitro and mouse tissue in vivo. Nevertheless, the toxicity of Au NPs can be dose-dependent, ie, Au NPs can be toxic at 500 and 1,000 $\mu \mathrm{M}$, but possess no apparent toxicity at $\leq 100 \mu \mathrm{M}$ (Figure 4). A similar outcome was demonstrated by Shukla et al, ${ }^{36}$ reporting $>90 \%$ viability for RAW 264.7 cells after 48 hours of treatment with $\mathrm{Au}$ NPs at $\leq 100 \mu \mathrm{M}$, while no noticeable increase in proinflammatory cytokines such as tumor necrosis factor- $\alpha$ and interleukin- $1 \beta$. Further, phagocytes such as macrophages and monocytes can react more strongly with microparticles than with NPs. ${ }^{37}$ For instance, Morishige et $\mathrm{a}^{138}$ did not observe any cytotoxicity towards THP- 1 cells in the presence of 30-70 nm silica NPs, but 1,000 nm particles did have a cytotoxic effect. Thus, it may be postulated that 
the cytotoxicity of $\mathrm{Au}$ NPs at 500 and $1,000 \mu \mathrm{M}$ may be attributable to the tendency of phagocytes like RAW 264.7 cells to agglomerate, resulting in higher cytotoxicity towards phagocytic RAW 264.7 cells.

Conversely, all the three types of as-synthesized NPs showed substantial cytotoxicity towards A549 lung cancer cells, with $\mathrm{Au} / \mathrm{CeO}_{2}$ NPs having a greater inhibitory effect than $\mathrm{Au}$ NPs or $\mathrm{CeO}_{2}$ NPs for both the 24-hour and 48-hour treatments (Figure 5). While several studies have demonstrated their antioxidant behavior in normal cells, $\mathrm{CeO}_{2}$ NPs could also have cytotoxic effects in several types of cancer cells. ${ }^{39,40}$ For example, Tarnuzzer et $\mathrm{al}^{31}$ have shown $\mathrm{CeO}_{2}$ NPs to have a radioprotective effect in normal human CRL8798 breast cells but not in human MCF-7 breast cancer cells. Likewise, using $\mathrm{CeO}_{2}$ NPs codoped with yttrium and erbium, Babu et $\mathrm{al}^{30}$ noticed a cytoprotective effect in normal cells, such as human umbilical vein endothelial cells and human lung fibroblast cells (WI-38), but the viability of CRL-5803 lung cancer cells was decreased by $34 \%$ even at a dose of $100 \mathrm{nM}$.

Prior to internalization and localization in cellular organelles, binding of NPs onto the cell membrane is the determining factor for their cellular uptake, which can be dependent upon the surface charge of both NPs and the cell surface. ${ }^{41}$ After binding of NPs to the cell membrane, uptake occurs via several mechanisms, such as pinocytosis or receptor-mediated endocytosis or phagocytosis. ${ }^{39,41}$ As shown in Figure 6, the positive zeta potentials of $\mathrm{CeO}_{2} \mathrm{NPs}$ and $\mathrm{Au} / \mathrm{CeO}_{2} \mathrm{NPs}$ in freshly prepared solution $(+41.5 \mathrm{mV}$ and $+55.6 \mathrm{mV}$, respectively) was shifted to negative in 24 hours $(-24.2 \mathrm{mV}$ and $-8.5 \mathrm{mV})$ and further to $-38.2 \mathrm{mV}$

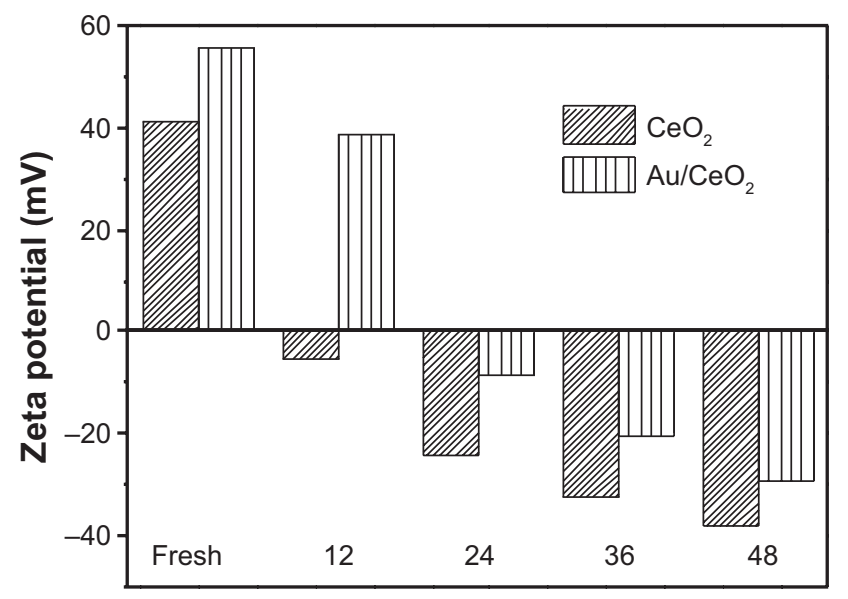

Time (hours)

Figure 6 Zeta potential of prepared $\mathrm{CeO}_{2}$ and $\mathrm{Au} / \mathrm{CeO}_{2}$ solutions monitored at regular intervals for 48 hours.

Abbreviations: $\mathrm{Au}$, gold; $\mathrm{CeO}_{2}$, cerium oxide; $\mathrm{Au} / \mathrm{CeO}_{2}$, gold-coated cerium oxide. and $-29.6 \mathrm{mV}$ in 48 hours. Such switching of surface charge has been reported previously by Vincent et al ${ }^{42}$ who showed a shift in zeta potential from positive to negative following an increase in incubation time (over 4 days) and temperature (over $65^{\circ} \mathrm{C}$ ). However, in our study, this charge shift was evident after 24 hours of incubation during the cytotoxicity test. Likewise, a negative mean zeta potential of $-10.2 \mathrm{mV}$ was reported for A549 cancer cells by Patil et $\mathrm{al}^{41}$ implying that only a few cationic sites are available for binding to negatively charged NPs. Obviously, negatively charged A549 cells should repel NPs of similar charge. Nonetheless, it is also possible that the negatively charged NPs may bind in clusters at cationic sites on A549 cells because of the repulsive force from a large pool of negatively charged sites on the cell surface, as pointed out by Patil et al. ${ }^{41}$ Asati et al ${ }^{43}$ also demonstrated efficient uptake of negatively charged polyacrylic acidcoated $\mathrm{CeO}_{2} \mathrm{NPs}$, with internalization into lysosomes and eventual cytotoxicity towards A549 cells. Accordingly, the negatively charged NPs may be clustered onto less populated and positively charged sites on the surface of the A549 cell via electrostatic interaction, which in turn may lead to localized neutralization of charge and subsequent cellular uptake by endocytosis.

The selective toxicity towards cancer cells may be explained on the basis of the unique $\mathrm{pH}$-dependent antioxidant behavior of $\mathrm{CeO}_{2} \mathrm{NPs}$ as proposed by Perez et $\mathrm{al}^{44}$ who found that their optimal antioxidant properties occurred at physiological $\mathrm{pH}$, whereas their oxidase (pro-oxidant) activity occurred at acidic $\mathrm{pH}$. In a later study, Asati et $\mathrm{al}^{43}$ postulated that internalization and localization of negatively charged $\mathrm{CeO}_{2} \mathrm{NPs}$ in the lysosomes (an acidic environment) of A549 cells should switch off their antioxidant activity and turn on their oxidase activity. This phenomenon, known as the "Warburg effect", occurs as a result of enhanced glycolysis and lactate production via activation of hypoxia inducible factor- $1 \alpha$ caused by the elevated levels of ROS in tumor cells. ${ }^{35}$ Thus, in our study, the cytotoxicity of $\mathrm{CeO}_{2}$ $\mathrm{NPs}$ and $\mathrm{Au} / \mathrm{CeO}_{2} \mathrm{NPs}$ towards A549 cells may be ascribed to the pro-oxidant activity induced by their internalization and localization into the acidic environment found in lysosomes. Obviously, the NPs can produce ROS upon induction of oxidase activity, leading to oxidative stress and eventually apoptosis of A549 cells. In a similar study, Lin et al ${ }^{45}$ observed significant oxidative stress in A549 cells because of a reduction in glutathione and $\alpha$-tocopherol levels, resulting in lipid peroxidation and subsequent damage to the cell membrane. 

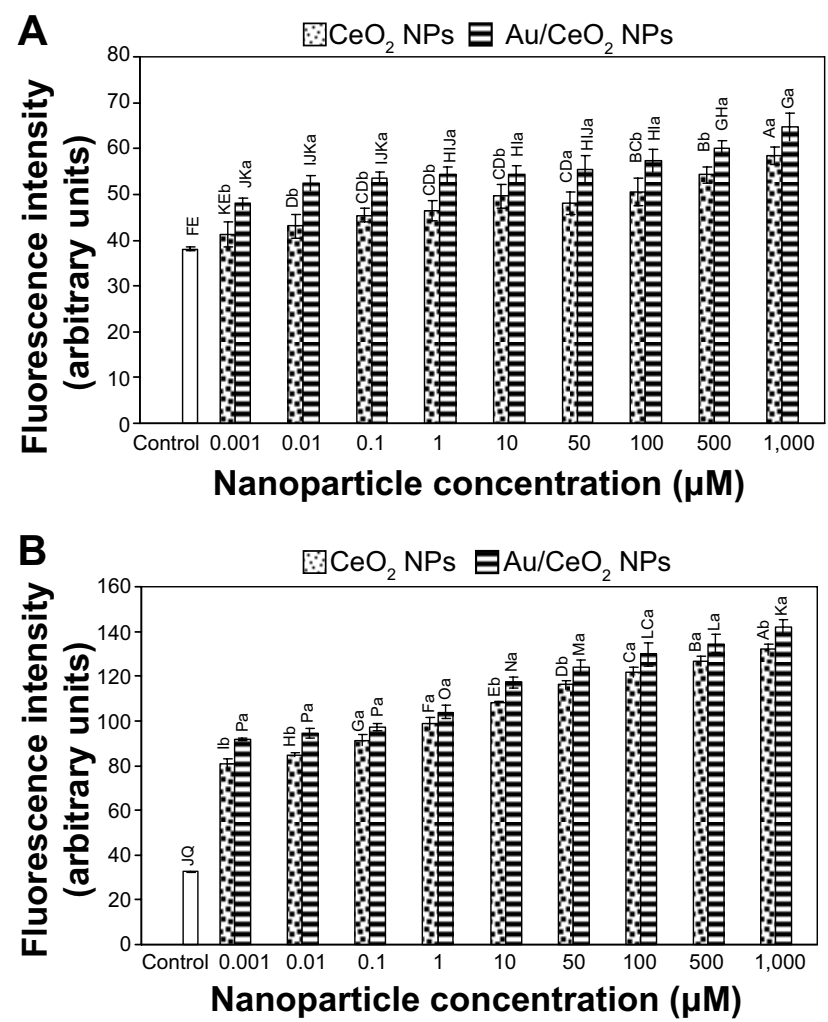

Figure 7 Formation of intracellular reactive oxygen species after 24 hours $(\mathbf{A})$ and 48 hours (B) of incubation with nanoparticles. Data with alphabetical letters (A-Q and $\mathrm{a}, \mathrm{b})$ indicate statistically significant values $(P<0.05)$.

Abbreviations: $\mathrm{Au}$, gold; $\mathrm{CeO}_{2}$, cerium oxide; $\mathrm{Au} / \mathrm{CeO}_{2}$, gold-coated cerium oxide; NPs, nanoparticles.

To further elucidate the inhibition mechanism in A549 cells, intracellular ROS production was measured using the same NP dose as that used in the cytotoxic study $(0.001-1,000 \mu \mathrm{M})$. Figure 7A and B show the production of ROS in terms of fluorescence intensity as a function of NP dose after 24 and 48 hours of incubation, respectively. For both $\mathrm{CeO}_{2} \mathrm{NPs}$ and $\mathrm{Au} / \mathrm{CeO}_{2} \mathrm{NPs}$, generation of ROS increased in a dose-dependent manner, with a 2-3-fold increase when the incubation time increased from 24 hours to 48 hours. Compared with the control, generation of ROS increased after 24 hours by $45.3 \%$ for $\mathrm{CeO}_{2} \mathrm{NPs}$ and by $44.1 \%$ for $\mathrm{Au} / \mathrm{CeO}_{2} \mathrm{NPs}$, while relatively to a larger extent by $158.1 \%$ for $\mathrm{CeO}_{2} \mathrm{NPs}$ and by $154.5 \%$ for $\mathrm{Au} / \mathrm{CeO}_{2} \mathrm{NPs}$ after 48 hours of treatment, indicating that the latter could induce more ROS production than the former, probably as a result of the ability of Au to prevent agglomeration of $\mathrm{Au} / \mathrm{CeO}_{2} \mathrm{NPs}$. As mentioned before, although $\mathrm{CeO}_{2} \mathrm{NPs}$ possess unique autoregenerative antioxidant activity, they can also behave as pro-oxidants depending on the compartment where they become localized inside the cell., 57,34 Obviously, the tumor progression, invasion, metastasis, and the acidic tumor environment are closely interrelated. ${ }^{42}$ The difference between normal cells and cancer cells may also play a crucial role in determining the antioxidant or pro-oxidant behavior of $\mathrm{CeO}_{2} \mathrm{NPs}^{42}$ Accordingly, the ROS production observed in our study should be due to the prooxidant activity of $\mathrm{CeO}_{2}$, because A549 lung carcinoma cells have an inherently acidic environment resulting from upregulated glycolysis and increased lactic acid production. Nevertheless, Asati et a ${ }^{42}$ demonstrated that localization of $\mathrm{CeO}_{2}$ NPs in the cytoplasm induces low or no cytotoxicity, while internalization inside lysosomes results in profound toxicity to cells.

In order to verify cellular uptake of NPs and their intracellular localization, cells incubated with NPs for 48 hours were pelleted and TEM images were recorded (Figure 8A-L). It is evident from these images that both $\mathrm{CeO}_{2} \mathrm{NPs}$ and $\mathrm{Au} / \mathrm{CeO}_{2}$ NPs were internalized into A549 cancer cells, with NPs becoming agglomerated (Figure 8D, $\mathrm{E}, \mathrm{J}$, and $\mathrm{K}$ ), probably because of the high NP dose used $(1,000 \mu \mathrm{M})$. However, the size and shape of the NPs were clearly visible (Figure $8 \mathrm{E}$ and $\mathrm{K}$ ) and seemed to be unchanged even after internalization. In addition, both types of NPs were predominantly localized inside the cytoplasmic matrix around the nucleus (Figure 8C and I). However, whether they were localized in the endoplasmic, vesicular, or cytosol compartments was difficult to distinguish from the TEM images. The localization of a high proportion of NPs in the cytoplasm should be the main reason for their cytotoxicity towards A549 cells only at higher doses $(100-1,000 \mu \mathrm{M})$. It may also be inferred that, at high doses, a certain proportion of the NPs may penetrate into lysosomes to induce higher toxicity in an acidic environment. In addition, the substantial increase in oxidative stress caused by ROS production may lead to mitochondrial dysfunction, as seen in Figure $8 \mathrm{~F}$ and $\mathrm{L}$. Taken together, it may be postulated that the cytotoxicity in A549 cells may be caused by the pro-oxidant activity of $\mathrm{CeO}_{2} \mathrm{NPs}$ or $\mathrm{Au} / \mathrm{CeO}_{2} \mathrm{NPs}$, leading to oxidative stress and mitochondrial dysfunction.

\section{Antibacterial activity of $\mathrm{Au}, \mathrm{CeO}_{2}$ and $\mathrm{Au} / \mathrm{CeO}_{2} \mathrm{NPs}$}

The antibacterial activity of $\mathrm{Au} \mathrm{NPs}, \mathrm{CeO}_{2} \mathrm{NPs}$ and $\mathrm{Au} /$ $\mathrm{CeO}_{2}$ NPs was evaluated using E. coli, S. enteritidis, $B$. subtilis, and $S$. aureus as test pathogens in both monoculture and coculture systems. For the coculture studies, a lactic acid bacterium, L. plantarum, reported to have antibacterial activity, ${ }^{15,20}$ was cocultured along with each test pathogen. The observed 

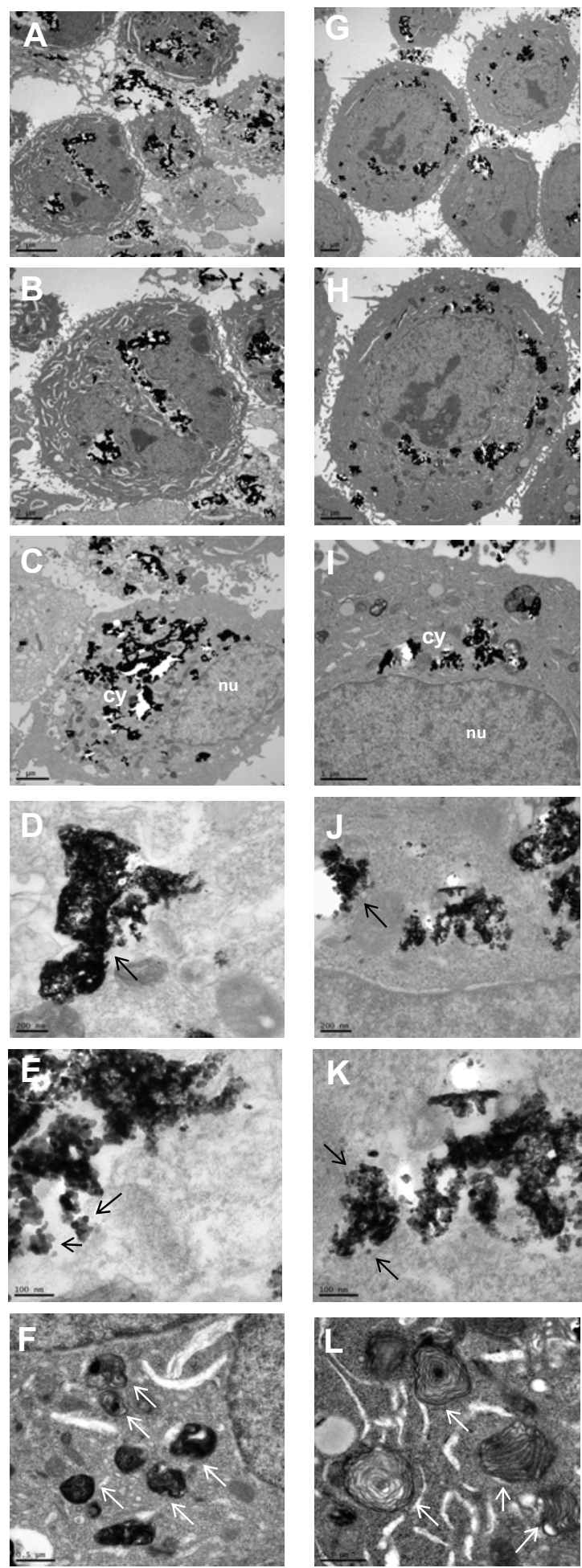

Figure 8 Transmission electron microscopic images showing the cellular uptake of $\mathrm{CeO}_{2} \mathrm{NPs}(\mathbf{A}-\mathbf{F})$ and $\mathrm{Au} / \mathrm{CeO}_{2} \mathrm{NPs}(\mathbf{G}-\mathbf{L})$ by $\mathrm{A} 549$ cells after 48 hours of incubation

Notes: (A, B) Cellular uptake of $\mathrm{CeO}_{2}$ NPs. (G, H) Cellular uptake of $\mathrm{Au} / \mathrm{CeO}_{2}$ NPs. (C, I) Nanoparticle localization in cytoplasmic matrix outside the nucleus. (D, J) Nanoparticle agglomeration inside the cell is shown as black arrows. (E, K) Individual nanoparticles still seen inside the cell is shown as black arrows. (F, L) mitochondrial damage due to oxidative stress induced by ROS is shown as white arrows.

Abbreviations: cy, cytoplasmic matrix; $\mathrm{Au}$, gold; $\mathrm{CeO}_{2}$, cerium oxide; $\mathrm{Au} / \mathrm{CeO}_{2}$, gold-coated cerium oxide; NPs, nanoparticles; nu, nucleus. antibacterial efficiency of the NPs was also compared with that of two commercial antibiotics, ampicillin and vancomycin. Figures 9 and 10 show the changes in bacterial concentration resulting from exposure to the different types of NPs and antibiotics in the monoculture and coculture studies, respectively. The overlap of NP absorbance and bacterial optical density was eliminated by accounting for the optical density of the bacterial inoculum containing NPs at 0 hour. The NPs did not dramatically inhibit growth of the bacterial strains at a low dose, so the minimum inhibitory concentration was not determined. This is the reason why the serial dilution method was used to evaluate the inhibitory effects of the NPs on the bacteria tested.

$\mathrm{Au}$ NPs did not have any significant inhibitory effect on the tested bacterial strains in either the monoculture or coculture studies. However, in the monoculture studies, both $\mathrm{CeO}_{2} \mathrm{NPs}$ and $\mathrm{Au} / \mathrm{CeO}_{2} \mathrm{NPs}$ inhibited the growth of all tested pathogens, with the effects being higher for $B$. subtilis and $S$. enteritidis when compared with $E$. coli and $S$. aureus (Figure 9). Despite some inconsistency at the initial doses $(6$ and $12 \mu \mathrm{M})$, the percentage inhibition achieved by both NPs showed a dose-dependent increase for all types of bacteria. More specifically, following a rise in NP concentration from 0 to $1,488 \mu \mathrm{M}$, the antibacterial activity of $\mathrm{CeO}_{2}$ NPs and $\mathrm{Au} / \mathrm{CeO}_{2}$ NPs increased by $52.3 \%$ and $69.6 \%$ for B. subtilis, by $40.9 \%$ and $45.7 \%$ for $S$. enteritidis, by $25.2 \%$ and $38.2 \%$ for $E$. coli, and by $12.4 \%$ and $24.2 \%$ for $S$. aureus, respectively, indicating that the inhibitory effect of the NPs was broad spectrum regardless of whether the bacteria were Gram-positive or Gram-negative (Figure 9). Compared with the antibiotics, ie, ampicillin and vancomycin, at $1,488 \mu \mathrm{M}$, the antibacterial efficiency of $\mathrm{CeO}_{2} \mathrm{NPs}$ and $\mathrm{Au} / \mathrm{CeO}_{2}$ NPs relative to ampicillin was $41.4 \%$ and $46.3 \%$ higher for $S$. enteritidis, $25.2 \%$ and $38.2 \%$ higher for E. coli, $12.6 \%$ and $24.6 \%$ higher for $S$. aureus, and $49.6 \%$ and $66.9 \%$ higher for $B$. subtilis, respectively. Whereas, the antibacterial efficiency of $\mathrm{CeO}_{2} \mathrm{NPs}$ and $\mathrm{Au} / \mathrm{CeO}_{2} \mathrm{NPs}$ relative to vancomycin was $52.3 \%$ and $69.6 \%$ higher for $B$. subtilis, $54.2 \%$ and $60.6 \%$ higher for $S$. enteritidis, $30.5 \%$ and $46.2 \%$ higher for E. coli, and $12.8 \%$ and $24.9 \%$ higher for $S$. aureus, respectively. Taken together, the test pathogens inhibited by both NPs in the monoculture tests showed the following order: B. subtilis $>$ S. enteritidis $>$ E. coli $>$ $S$. aureus. For further comparison, with a NP concentration of $1,488 \mu \mathrm{M}, \mathrm{Au} / \mathrm{CeO}_{2} \mathrm{NPs}$ had a greater antibacterial effect than $\mathrm{CeO}_{2}$ NPs for E. coli, S. enteritidis, B. subtilis, and $S$. aureus by $34 \%, 11 \%, 25 \%$, and $49 \%$, respectively. Of the two antibiotics, ampicillin was more efficient in inhibiting the growth of E. coli $(100 \%$ at $372 \mu \mathrm{M})$ and S. enteritidis 

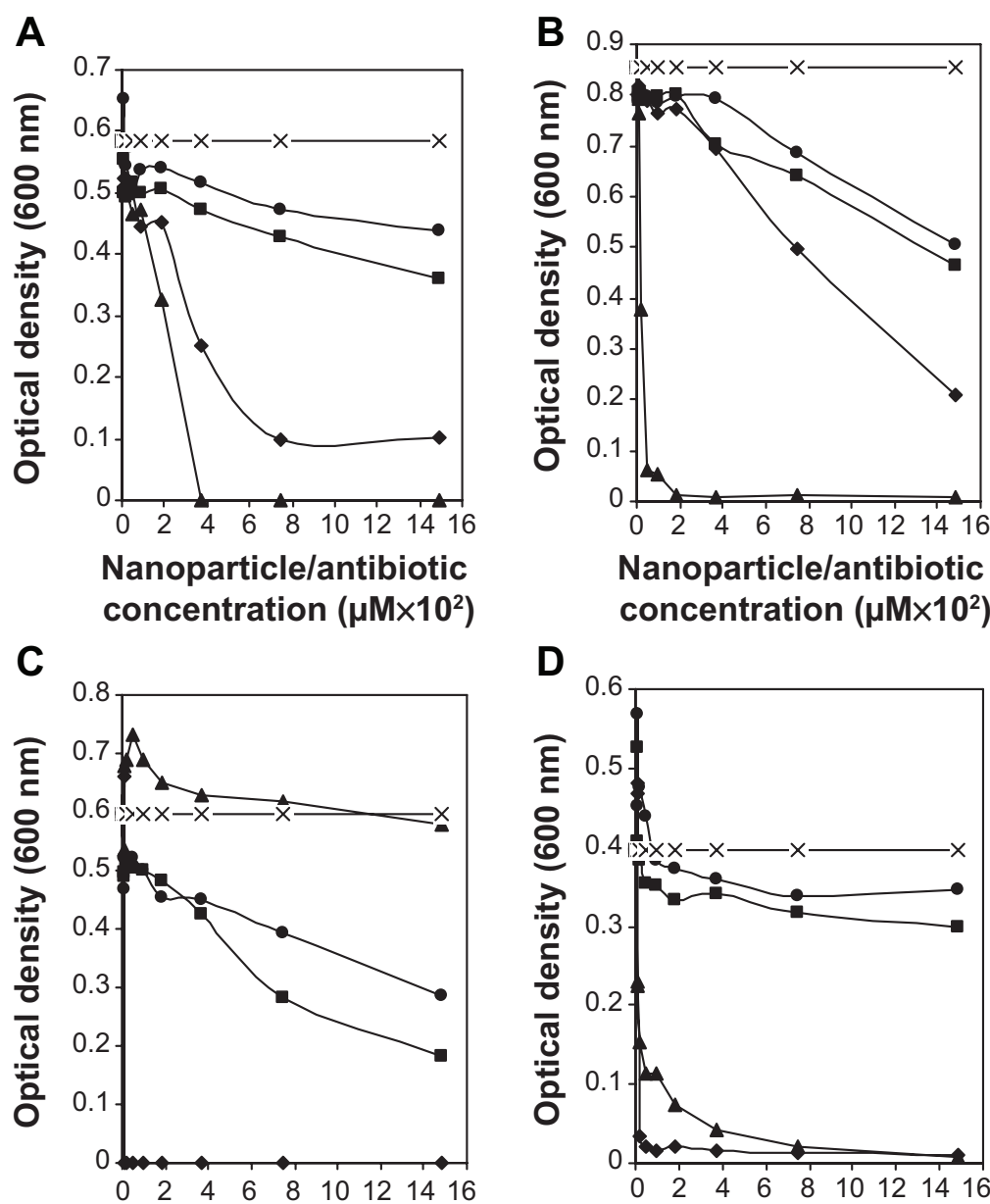

Nanoparticle/antibiotic concentration $\left(\mu \mathrm{M} \times 10^{2}\right)$

D

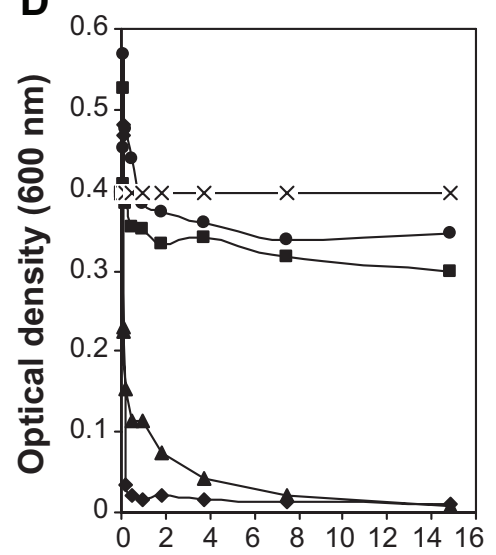

\section{Nanoparticle/antibiotic concentration $\left(\mu \mathrm{M} \times 10^{2}\right)$}

Figure 9 Changes in bacterial concentration as affected by different nanoparticles or antibiotic doses after incubation in a monoculture system for 16 hours. Test bacteria were (A) Escherichia coli, (B) Salmonella enteritidis, (C) Bacillus subtilis, and (D) Staphylococcus aureus.

Notes: Nanoparticle/antibiotic $(\times)$ Au nanoparticles, $(\bullet) \mathrm{CeO}_{2}$ nanoparticles, $(\boldsymbol{\square}) \mathrm{Au} / \mathrm{CeO}_{2} \mathrm{NPs},(\boldsymbol{\Delta})$ ampicillin, and $(\bullet)$ vancomycin.

Abbreviations: $\mathrm{Au}$, gold; $\mathrm{CeO}_{2}$, cerium oxide; $\mathrm{Au} / \mathrm{CeO}_{2}$, gold-coated cerium oxide; NPs, nanoparticles.

$(93.0 \%$ at $47 \mu \mathrm{M})$ than vancomycin $(82.7 \%$ and $75.4 \%$ for both bacteria at $1,488 \mu \mathrm{M})$, while vancomycin completely destroyed $B$. subtilis at a lower dose of $12 \mu \mathrm{M}$. Although ampicillin is a broad-spectrum drug, it failed to show pronounced antibacterial activity towards Gram-positive $B$. subtilis. Nevertheless, both antibiotics had high antibacterial activity towards $S$. aureus. The variation in inhibitory effect towards the different bacterial strains may be due to a difference in antibacterial action, as ampicillin irreversibly inhibits the activity of transpeptidase, an enzyme required for cell wall synthesis, while vancomycin acts by inhibiting cross-linking in the cell wall.

In bacterial systems cocultured with L. plantarum, $S$. aureus was retarded to a greater extent by both $\mathrm{CeO}_{2}$ NPs and $\mathrm{Au} / \mathrm{CeO}_{2} \mathrm{NPs}$, followed by E. coli, B. subtilis, and S. enteritidis (Figure 10). This trend was the opposite to that observed in monoculture studies, in which both NPs showed the lowest anti-S. aureus activity, implying that coculture of L. plantarum with $S$. aureus could enhance the antibacterial activity of $\mathrm{CeO}_{2}$ NPs and $\mathrm{Au} / \mathrm{CeO}_{2}$ NPs towards antibioticresistant $S$. aureus (Figures 9 and 10). In addition, inhibition of $E$. coli by $\mathrm{CeO}_{2}$ NPs increased by $20 \%$ compared with monoculture systems, but no significant change was noted for $\mathrm{Au} / \mathrm{CeO}_{2} \mathrm{NPs}$. In contrast, the antibacterial activity towards $S$. enteritidis and B. subtilis dropped by $6 \%$ and $12.1 \%$ for $\mathrm{CeO}_{2}$ $\mathrm{NPs}$, respectively, whereas a much higher inhibition $(14.3 \%$ and $31.2 \%$, respectively) was shown for $\mathrm{Au} / \mathrm{CeO}_{2} \mathrm{NPs}$. Following an increase in NP concentration from 0 to $1,488 \mu \mathrm{M}$, the percent inhibition of $S$. aureus, E. coli, B. subtilis, and $S$. enteritidis by $\mathrm{CeO}_{2} \mathrm{NPs}$ and $\mathrm{Au} / \mathrm{CeO}_{2} \mathrm{NPs}$ increased by $45.7 \%$ and $42.1 \%, 44.7 \%$ and $41.2 \%, 40.2 \%$ and $38.4 \%$, and $34.9 \%$ and $31.4 \%$, respectively (Figure 10). Compared to monoculture 
A

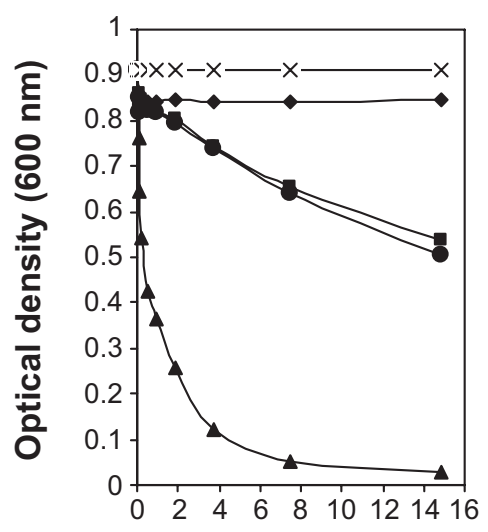

Nanoparticle/antibiotic concentration $\left(\mu \mathrm{M} \times 10^{2}\right)$

C

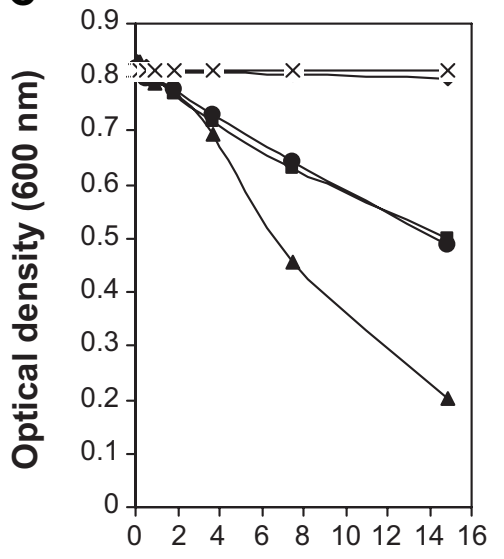

Nanoparticle/antibiotic concentration $\left(\mu \mathrm{M} \times 10^{2}\right)$
B

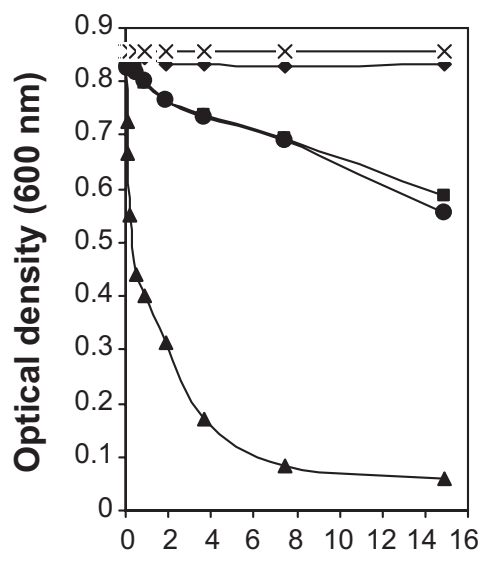

Nanoparticle/antibiotic concentration $\left(\mu \mathrm{M} \times 10^{2}\right)$

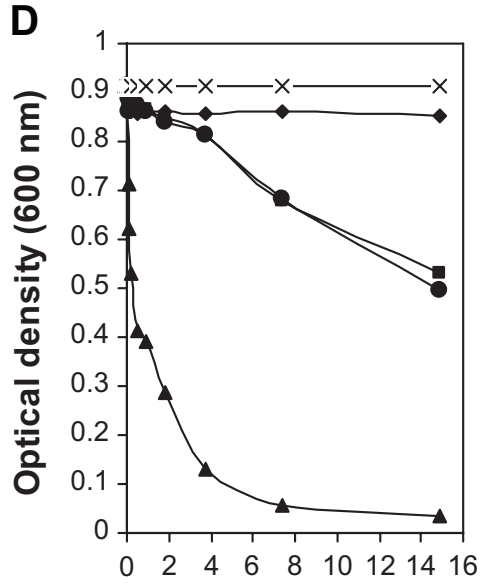

Nanoparticle/antibiotic concentration $\left(\mu \mathrm{M} \times 10^{2}\right)$

Figure 10 Changes in bacterial concentration as affected by different nanoparticles or antibiotics dose after incubation in a coculture system for 16 hours. Test bacteria were (A) Escherichia coli, (B) Salmonella enteritidis, (C) Bacillus subtilis, and (D) Staphylococcus aureus.

Notes: Nanoparticle/antibiotic $(\times)$ Au nanoparticles, $(\bullet) \mathrm{CeO}_{2}$ nanoparticles, (ロ) $\mathrm{Au} / \mathrm{CeO}, \mathrm{NPs},(\boldsymbol{\Delta})$ ampicillin, and $(\bullet)$ vancomycin

Abbreviations: $\mathrm{Au}$, gold; $\mathrm{CeO}_{2}$, cerium oxide; $\mathrm{Au} / \mathrm{CeO}_{2}$, gold-coated cerium oxide; NPs, nanoparticles.

treatment without L. plantarum, the antibacterial efficiency of NPs towards Gram-positive and Gram-negative bacteria followed a reverse trend with $S$. aureus $>$ B. subtilis for the former and E. coli $>$ S. enteritidis for the latter." Unlike the monoculture system, a uniform trend was observed for inhibition of all the bacteria by NPs and antibiotics in the presence of L. plantarum, in the following order: ampicillin $>\mathrm{CeO}_{2}$ $\mathrm{NPs}>\mathrm{Au} / \mathrm{CeO}_{2} \mathrm{NPs}>>$ vancomycin. Of all the various treatments, NPs at 1,488 $\mu \mathrm{M}$ showed superior antibacterial activity when compared with vancomycin, with 32\%-39\% higher inhibition efficiency for $\mathrm{CeO}_{2}$ and $29 \%-37 \%$ higher inhibition efficiency for $\mathrm{Au} / \mathrm{CeO}_{2}$. However, the inhibition efficiency of $\mathrm{CeO}_{2}$ NPs and $\mathrm{Au} / \mathrm{CeO}_{2} \mathrm{NPs}$ was $46.1 \%$ and $42.5 \%$ higher relative to ampicillin for E. coli, $37.5 \%$ and $33.7 \%$ higher for $S$. enteritidis, $79.7 \%$ and $51.2 \%$ higher for
B. subtilis, and $47.5 \%$ and $43.8 \%$ higher for S. aureus, respectively. Thus, in the presence of $L$. plantarum, inhibition of $S$. aureus by ampicillin was greatly enhanced compared with the same treatment in monoculture systems.

It has been well documented that the antibacterial activity of $\mathrm{CeO}_{2}$ NPs depends mainly on the surface charge and oxidoreductive ability of the cerium atoms. ${ }^{46,47}$ According to zeta potential measurements, as shown in Figure 6, the surface charge on $\mathrm{CeO}_{2} \mathrm{NPs}$ and $\mathrm{Au} / \mathrm{CeO}_{2} \mathrm{NPs}$ showed positive values of $41.5 \mathrm{mV}$ and $55.6 \mathrm{mV}$, respectively, in freshly prepared solution. As mentioned earlier under results and discussion of cytotoxic study, the zeta potential shifted gradually from positive to negative with time, reaching $-24.2 \mathrm{mV}$ and $-8.5 \mathrm{mV}$ after 24 hours and $-38.2 \mathrm{mV}$ and $-29.6 \mathrm{mV}$ after 48 hours. Because the NP dispersion was prepared just before 
the start of the antibacterial experiments, this shift in surface charge over a 16-hour incubation period should be responsible for significant toxicity in both Gram-positive and Gram-negative bacteria. Also, the interaction of both NPs with Gram-negative bacteria might occur during the initial period of incubation when the surface charge of both NPs is positive, whereas a shift in the surface charge of the NPs to negative during the later period of incubation may favor a predominant interaction with Grampositive bacteria. In a study dealing with the cytotoxicity of commercial $\mathrm{CeO}_{2} \mathrm{NPs}$ in Gram-negative E. coli, rapid toxicity occurred upon adsorption of NPs on the cell membrane after one hour and remained constant until 5 hours. ${ }^{46}$ Upon adsorption via electrostatic interaction, the cerium atoms on NPs may undergo reduction from $\mathrm{Ce}^{4+}$ to $\mathrm{Ce}^{3+}$ on the cell surface, eventually leading to oxidative stress and cytotoxicity to bacteria. ${ }^{46,48}$ Further, the bacterial growth may also be affected by modification of nutrient transport on the outer cell membranes through alteration in membrane viscosity and corruption of specific ionic pumps. ${ }^{49}$ With regard to inhibition of $E$. coli by commercial $\mathrm{CeO}_{2} \mathrm{NPs}_{\text {, }}$ Thill et $\mathrm{al}^{46}$ pointed out that a direct spatial contact is essential for inducing cytotoxicity in bacteria.

The difference in inhibitory effect between Gram-positive and Gram-negative bacteria may be due to variations in the membrane surface, surface charge density, and metabolic process. Of the two Gram-positive bacteria tested, B. subtilis was inhibited to a greater extent by both NPs than was S. aureus, which may be ascribed to a spore-forming tendency and the presence of a high content of hydrophilic proteins on the cell surface of the former. ${ }^{48}$ Inbaraj et al ${ }^{50}$ have recently shown that the hydrophilic nature of bacteria can influence the antibacterial activity of metal oxide NPs. Likewise, the extracellular polymeric substance produced by Gram-negative E. coli $\mathrm{O} 157: \mathrm{H} 7$ may block electrostatic interaction between NPs and the cell membrane, which in turn may decrease the inhibitory effect when compared with $S$. enteritidis. A similar phenomenon was observed by Zeyons et $\mathrm{al}^{49}$ and Inbaraj et $\mathrm{al}^{51}$ with regard to inhibition of extracellular polymeric substanceproducing Synechocystis and E. coli O157:H7 by $\mathrm{CeO}_{2} \mathrm{NPs}$ and $\mathrm{Fe}_{3} \mathrm{O}_{4} \mathrm{NPs}$, respectively. In addition, categorization of $E$. coli $\mathrm{O} 157: \mathrm{H} 7$ as "slightly charged in relative to $S$. enteritidis may also explain its lower antibacterial activity by both NPs. ${ }^{51}$ The relatively stronger antibacterial effect shown by $\mathrm{Au} / \mathrm{CeO}_{2}$ NPs than by $\mathrm{CeO}_{2}$ NPs may be due to a better suspension being achieved by coating of $\mathrm{Au}$ onto $\mathrm{CeO}_{2}$. Biradar et $\mathrm{al}^{7}$ have recently demonstrated that incorporation of Au can enhance the antibacterial activity of commercial antibiotics when used as combination therapy against $S$. aureus, E. coli, Pseudomonas aeruginosa, and Klebsiella pneumoniae. However, in coculture studies, both $\mathrm{CeO}_{2} \mathrm{NPs}$ and $\mathrm{Au} / \mathrm{CeO}_{2}$ NPs exhibited a similar inhibitory effect against all tested bacteria, and the mechanism needs to be explored further (Figure 10). The Gram-positive $L$. plantarum used in the coculture experiment may have modulated the inhibitory effect of both NPs by masking the benefits of $\mathrm{Au}$ decoration over $\mathrm{CeO}_{2} \mathrm{NPs}$.

As mentioned in the previous section, bacteriocins alone or in combination with other metabolites produced during the L. plantarum culture experiment may be responsible for this modulating effect on the antibacterial activity of both NPs. ${ }^{18,21}$ Moreover, the low inhibitory effect of $\mathrm{CeO}_{2} \mathrm{NPs}$ on E. coli $\mathrm{O} 157: \mathrm{H} 7$ and that of both NPs on S. aureus in the monoculture tests was substantially enhanced by coculture with L. plantarum. As pointed out by François et $\mathrm{al}^{15}$ and Sharif et al, ${ }^{20}$ L. plantarum can effectively inhibit the growth of E. coli and S. aureus. Similarly, a Lactobacillus species was shown to be effective against $S$. aureus in two other studies. ${ }^{14,17}$ Thus, by combining isolates from Lactobacillus species, the antibacterial activity of $\mathrm{CeO}_{2}$ NPs towards $E$. coli and $S$. aureus could be greatly enhanced.

While several studies have evaluated the toxicity of metal oxide NPs, mainly in mammalian cells, few studies have investigated the antibacterial effect of $\mathrm{CeO}_{2} \mathrm{NPs}$. Some studies have shown inconsistent results for bacterial inhibition by $\mathrm{CeO}_{2}$ NPs. For instance, Thill et $\mathrm{al}^{46}$ and Pelletier et $\mathrm{al}^{48}$ have observed substantial toxicity towards $E$. coli bacteria because of oxidative stress through direct adsorption of $\mathrm{CeO}_{2}$ NPs onto the cell surface. However, several authors have found very little toxicity under room lighting and at room temperature. ${ }^{6,52}$ This difference in NP toxicity can be dependent upon surface charge as well as the physicochemical environment. ${ }^{1,46,48}$ In previous studies, both Kartsonakis et $\mathrm{al}^{52}$ and Li et al $^{53}$ observed a marked decrease in E. coli concentration upon illumination of $\mathrm{CeO}_{2} \mathrm{NPs}$ in bacterial systems, with a minimum effect being noticed in a non-illuminated environment. Variations in $\mathrm{pH}$, growth medium, particle size, and NP concentrations could alter the toxicity of $\mathrm{CeO}_{2} \mathrm{NPs}$ towards bacteria. By comparing uncoated and coated NPs, Kartsonakis et $\mathrm{al}^{52}$ demonstrated that polypyrrole-coated and polyaniline-coated $\mathrm{CeO}_{2}$ NPs had a better inhibitory effect against $E$. coli. Nevertheless, for dextran-coated $\mathrm{CeO}_{2}$ NPs, a non-lethal response was shown by Shah et $\mathrm{al}^{1}$ under varying physical and chemical environments, including $\mathrm{pH}$, aeration, salt concentration $\left(\mathrm{MgSO}_{4}, \mathrm{CaCl}_{2}\right.$, and $\left.\mathrm{KCl}\right)$, natural organic matter, and fructose. Thus, bacterial interactions with NPs depend on many factors, making elucidation of the mechanism of inhibition a complicated issue. Future mechanistic investigations involving detailed imaging experiments 
and molecular analysis could facilitate understanding of the toxicity of NPs towards various microorganisms.

\section{Conclusion}

In summary, the present work describes the synthesis of porous $\mathrm{CeO}_{2} \mathrm{NPs}$ by a combustion method and subsequent support with Au using a deposition-precipitation method. As-prepared $\mathrm{CeO}_{2} \mathrm{NPs}$ and $\mathrm{Au} / \mathrm{CeO}_{2} \mathrm{NPs}$ were tested for cytotoxicity towards normal RAW 264.7 macrophage cells and A549 lung cancer cells as well as their antibacterial activity towards Gram-positive and Gram-negative bacteria. Au-supported $\mathrm{CeO}_{2}$ NPs showed better biocompatibility with normal RAW 264.7 macrophage cells, but inhibited the growth of A549 adenocarcinoma epithelial cells. This outcome demonstrated better selectivity of $\mathrm{Au} / \mathrm{CeO}_{2} \mathrm{NPs}$ towards cancerous cells in a concentration-dependent manner than $\mathrm{CeO}_{2}$ NPs. Also, the antibacterial activity of $\mathrm{CeO}_{2}$ NPs and $\mathrm{Au} / \mathrm{CeO}_{2}$ NPs towards various bacterial species such as E. coli, S. enteritidis, B. subtilis, and S. aureus suggests that, compared with pure $\mathrm{Au}, \mathrm{Au} / \mathrm{CeO}_{2} \mathrm{NPs}$ exhibited a better antibacterial effect, while $\mathrm{CeO}_{2} \mathrm{NPs}$ and $\mathrm{Au} / \mathrm{CeO}_{2}$ NPs inhibited $B$. subtilis and $S$. enteritidis in preference to $E$. coli and $S$. aureus. In bacterial systems cocultured with L. plantarum, inhibition of $S$. aureus was greater with $\mathrm{CeO}_{2}$ NPs and $\mathrm{Au} / \mathrm{CeO}_{2}$ NPs. Au-supported $\mathrm{CeO}_{2} \mathrm{NPs}$ may be a potential nanomaterial for in vivo application owing to their biocompatible and antibacterial properties.

\section{Acknowledgments}

KSB acknowledges start-up grant support (PU/PC/Start-up Grant/2011-12/312) provided by Pondicherry University. The authors are grateful to the Central Instrumentation Facility, Pondicherry University, India, and to Professor Tzong Jwo Jang and $\mathrm{Mr}$ Yen-Sheng $\mathrm{Wu}$ in the Electron Microscope Laboratory, School of Medicine, Fu Jen University, Taipei, Taiwan, for transmission electron microscopy recordings and other characterizations. This study is also supported by a grant (NSC 101-2632-B-030-001-MY3) from the Ministry of Science and Technology, Taiwan.

\section{Disclosure}

The authors report no conflicts of interest in this work.

\section{References}

1. Shah V, Shah S, Shah H, et al. Antibacterial activity of polymer coated cerium oxide nanoparticles. PLoS One. 2012;7:e47827.

2. Aimei C, Qingshan S, Yousheng O, Yiben C. Effect of $\mathrm{Ce}^{3+}$ on membrane permeability of Escherichia coli cell. Journal of Rare Earths. 2012;30: 947-951.

3. Babu S, Velez A, Wozniak K, Szydlowska J, Seal S. Electron paramagnetic study on radical scavenging properties of ceria nanoparticles. Chem Phys Lett. 2007;442:405-408.
4. Song MF, Li YS, Kasai H, Kawa K. Metal nanoparticle-induced micronuclei and oxidative DNA damage in mice. J Clin Biochem Nutr. 2012;50:211-216.

5. Auffan $\mathrm{M}$, Rose J, Orsiere $\mathrm{T}$, et al. $\mathrm{CeO}_{2}$ nanoparticles induce DNA damage towards human dermal fibroblasts in vitro. Nanotoxicology. 2009;3:161-171.

6. Li Y, Zhang W, Niu J, Chen Y. Mechanism of photogenerated reactive oxygen species and correlation with the antibacterial properties of engineered metal-oxide nanoparticles. ACS Nano. 2012;6: 5164-5173.

7. Biradar D, Lingappa K, Dayanand A. Antibacterial activity of nano gold particles synthesized by Bacillus Sps. Journal of Ecobiotechnology. 2012;4:43-45.

8. Badwaik VD, Vangala LM, Pender DS, et al. Size-dependent antimicrobial properties of sugar-encapsulated gold nanoparticles synthesized by a green method. Nanoscale Res Lett. 2012;7:623.

9. Lima E, Guerra R, Lara V, Guzman A. Gold nanoparticles as efficient antimicrobial agents for Escherichia coli and Salmonella typhi. Chem Cent J. 2013;7:11.

10. Chen Y, Hung Y, Liau I, Huang GS. Assessment of the in vivo toxicity of gold nanoparticles. Nanoscale Res Lett. 2009;4:858-864.

11. Alkilany AM, Murphy CJ. Toxicity and cellular uptake of gold nanoparticles: what we have learned so far? J Nanopart Res. 2010;12: 2313-2333.

12. Soenen SJ, Manshian B, Montenegro JM, et al. Cytotoxic effects of gold nanoparticles: a multiparametric study. ACS Nano. 2012;6: $5767-5783$.

13. Menchón C, Martín R, Apostolova N, et al. Gold nanoparticles supported on nanoparticulate ceria as a powerful agent against intracellular oxidative stress. Small. 2012;8:1895-1903.

14. Anas M, Eddine HJ, Mebrouk K. Antimicrobial activity of Lactobacillus species isolated from Algerian raw goat's milk against Staphylococcus aureus. World Journal of Dairy and Food Sciences. 2008;3:39-49.

15. François ZN, Marie KP, Noëlle TAH, Emeric GWR. Antimicrobial activity of a bacteriocin produced by Lactobacillus plantarum $29 \mathrm{~V}$ and strain's viability in palm kernel oil. Int J Food Sci Nutr. 2013;2: 102-108.

16. Ravaei A, Pour ZH, Salehi TZ, Tamai IA, Ghane M, Pour JD. Evaluation of antimicrobial activity of three Lactobacillus spp. against antibiotic resistant Salmonella typhimurium. Adv Stud Biol. 2013;5:61-70.

17. Arokiyamary A, Sivakumar PK. Antibacterial activity of bacteriocin producing Lactobacillus sp., isolated from traditional milk products. Current Botany. 2011;2:5-8.

18. Asha, Gayathri D. Antagonistic potential of Lactobacillus spp against enterpathogenic bacteria; purification and characterization of their bacteriocins. Advance Journal of Food Science and Technology. 2012;4:265-269.

19. Šeatović S, Novaković JSJ, Zavišić GN, Radulović ZC, Jankulović MDG, Jankov RM. The partial characterization of the antibacterial peptide bacteriocin G2 produced by the probiotic bacteria Lactobacillus plantarum G2. J Serb Chem Soc. 2011;76:699-707.

20. Sharif H, Alidost L, Lababpour A, et al. Antibacterial activity of probiotic Lactobacillus plantarum HK01: effect of divalent metal cations and food additives on production efficiency of antibacterial compounds. Probiotics Antimicrob Proteins. 2013;5: 121-130.

21. Selvamohan T, Sujitha S. Antimicrobial activity of a probiotic Lactobacillus plantarum against urinary tract infection (UTI) causing pathogens. Der Pharmacia Lettre. 2010;2:432-440.

22. Zhang F, Liu N, Zhao P, et al. Gold on amine-functionalized magnetic nanoparticles: a novel and efficient catalyst for hydrogenation reactions. Appl Surf Sci. 2012;263:471-475.

23. Taguchi M, Takami S, Adschiri T, Nakane T, Sato K, Naka T. Supercritical hydrothermal synthesis of hydrophilic polymer-modified water-dispersible $\mathrm{CeO}_{2}$ nanoparticles. Cryst Eng Comm. 2011;13:2841-2848.

24. Jiao X, Song H, Zhao H, Bai W, Zhang L, Lv Y. Well-redispersed ceria nanoparticles: promising peroxidase mimetics for $\mathrm{H}_{2} \mathrm{O}_{2}$ and glucose detection. Anal Methods. 2012;4:3261-3267. 
25. Kominami H, Tanaka A, Hashimoto K. Gold nanoparticles supported on cerium(IV) oxide powder for mineralization of organic acids in aqueous suspensions under irradiation of visible light of $\lambda=530 \mathrm{~nm}$. Appl Catal A Gen. 2011;397:121-126.

26. Zhu F, Chen G, Sun S, Sun X. In situ growth of $\mathrm{Au} @ \mathrm{CeO}_{2}$ core-shell nanoparticles and $\mathrm{CeO}_{2}$ nanotubes from $\mathrm{Ce}(\mathrm{OH}) \mathrm{CO}_{3}$ nanorods. Journal of Materials Chemistry A. 2013;1:288-294.

27. Xia T, Kovochich M, Liong M, et al. Comparison of the mechanism of toxicity of zinc oxide and cerium oxide nanoparticles based on dissolution and oxidative stress properties. ACS Nano. 2008;2:2121-2134.

28. Korsvik A, Patil S, Seal S, Self WT. Superoxide dismutase mimetic properties exhibited by vacancy engineered ceria nanoparticles. Chem Commun (Camb). 2007;10:1056-1058.

29. Tsai YY, Oca-Cossio J, Agering K, et al. Novel synthesis of cerium oxide nanoparticles for free radical scavenging. Nanomedicine (Lond) 2007;2:325-332.

30. Babu S, Cho JH, Dowding JM, et al. Multicolored redox active upconverter cerium oxide nanoparticle for bio-imaging and therapeutics Chem Commun (Camb). 2010;46:6915-6917.

31. Tarnuzzer RW, Colon J, Patil S, Seal S. Vacancy engineering ceria nanostructures for protection from radiation-induced cellular damage. Nano Lett. 2005;5:2573-2577.

32. Hirst SM, Karakoti AS, Tyler RD, Sriranganathan N, Seal S, Reilly CM. Anti-inflammatory properties of cerium oxide nanoparticles. Small. 2009;5:2848-2856.

33. Colon J, Hsieh N, Ferguson A, et al. Cerium oxide nanoparticles protect gastrointestinal epithelium from radiation-induced damage by reduction of reactive oxygen species and upregulation of superoxide dismutase 2 . Nanomedicine. 2010;6:698-705.

34. Hussain S, Al-Nsour F, Rice AB, et al. Cerium dioxide nanoparticles induced apoptosis and autophagy in human peripheral blood monocytes. ACS Nano. 2012;6:5820-5829.

35. Alili L, Sack M, Karakoti AS, et al. Combined cytotoxic and antiinvasive properties of redox-active nanoparticles in tumor-stroma interactions. Biomaterials. 2011;32:2918-2929.

36. Shukla R, Bansal V, Chaudhary M, Basu A, Bhonde RR, Sastry M. Biocompatibility of gold nanoparticles and their endocytotic fate inside the cellular compartment: a microscopic overview. Langmuir. 2005;21:10644-10654.

37. Fröhlich E. The role of surface charge in cellular uptake and cytotoxicity of medical nanoparticles. Int J Nanomedicine. 2012;7:5577-5591.

38. Morishige $\mathrm{T}$, Yoshioka $\mathrm{Y}$, Inakura $\mathrm{H}$, et al. Cytotoxicity of amorphous silica particles against macrophage-like THP-1 cells depends on particle-size and surface properties. Pharmazie. 2010;65:596-599.
39. Wason MS, Zhao J. Cerium oxide nanoparticles: potential applications for cancer and other diseases. Am J Transl Res. 2013;5:126-131.

40. Celardo I, Pedersen PZ, Traversa E, Ghibelli L. Pharmacological potential of cerium oxide nanoparticles. Nanoscale. 2011;3:1411-1420.

41. Patil S, Sandberg A, Heckert E, Self W, Seal S. Protein adsorption and cellular uptake of cerium oxide nanoparticles as a function of zeta potential. Biomaterials. 2007;28:4600-4607.

42. Vincent A, Inerbaev TM, Babu S, et al. Tuning hydrated nanoceria surfaces: experimental/theoretical investigations of ion exchange and implications in organic and inorganic interactions. Langmuir. 2010;26:7188-7198.

43. Asati A, Santra S, Kaittanis C, Perez JM. Surface-charge-dependent cell localization and cytotoxicity of cerium oxide nanoparticles. ACS Nano. 2010;28:5321-5331.

44. Perez JM, Asati A, Nath S, Kaittanis C. Synthesis of biocompatible dextran-coated nanoceria with $\mathrm{pH}$-dependent antioxidant properties. Small. 2008;4:552-556.

45. Lin W, Huang Y, Zhou XD, Ma Y. Toxicity of cerium oxide nanoparticles in human lung cancer cells. Int J Toxicol. 2006;25:451-457.

46. Thill A, Zeyons $\mathrm{O}$, Spalla $\mathrm{O}$, et al. Cytotoxicity of $\mathrm{CeO}_{2}$ nanoparticles for Escherichia coli. Physico-chemical insight of the cytotoxicity mechanism. Environ Sci Technol. 2006;40:6151-6156.

47. He X, Kuang Y, Li Y, et al. Changing exposure media can reverse the cytotoxicity of ceria nanoparticles for Escherichia coli. Nanotoxicology. 2012;6:233-240.

48. Pelletier DA, Suresh AK, Holton GA, et al. Effects of engineered cerium oxide nanoparticles on bacterial growth and viability. Appl Environ Microbiol. 2010;76:7981-7989.

49. Zeyons O, Thill A, Chauvat F, et al. Direct and indirect $\mathrm{CeO}_{2}$ nanoparticle toxicity for Escherichia coli and Synechocystis. Nanotoxicology. 2009;3:284-295.

50. Inbaraj BS, Kao TH, Tsai TY, Chiu CP, Kumar R, Chen BH. The synthesis and characterization of poly $(\gamma$-glutamic acid)-coated magnetite nanoparticles and their effects on antibacterial activity and cytotoxicity. Nanotechnology. 2011;22:075101.

51. Inbaraj BS, Tsai TY, Chen BH. Synthesis, characterization and antibacterial activity of superparamagnetic nanoparticles modified with glycol chitosan. Sci Technol Adv Mater. 2012;13:015002.

52. Kartsonakis IA, Liatsi P, Daniilidis I, Kordas G. Synthesis, characterization, and antibacterial action of hollow ceria nanospheres with/without a conductive polymer coating. J Am Ceram Soc. 2008;91:372-378.
International Journal of Nanomedicine

\section{Publish your work in this journal}

The International Journal of Nanomedicine is an international, peerreviewed journal focusing on the application of nanotechnology in diagnostics, therapeutics, and drug delivery systems throughout the biomedical field. This journal is indexed on PubMed Central,

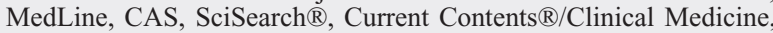

\section{Dovepress}

Journal Citation Reports/Science Edition, EMBase, Scopus and the Elsevier Bibliographic databases. The manuscript management system is completely online and includes a very quick and fair peer-review system, which is all easy to use. Visit http://www.dovepress.com/ testimonials.php to read real quotes from published authors. 